
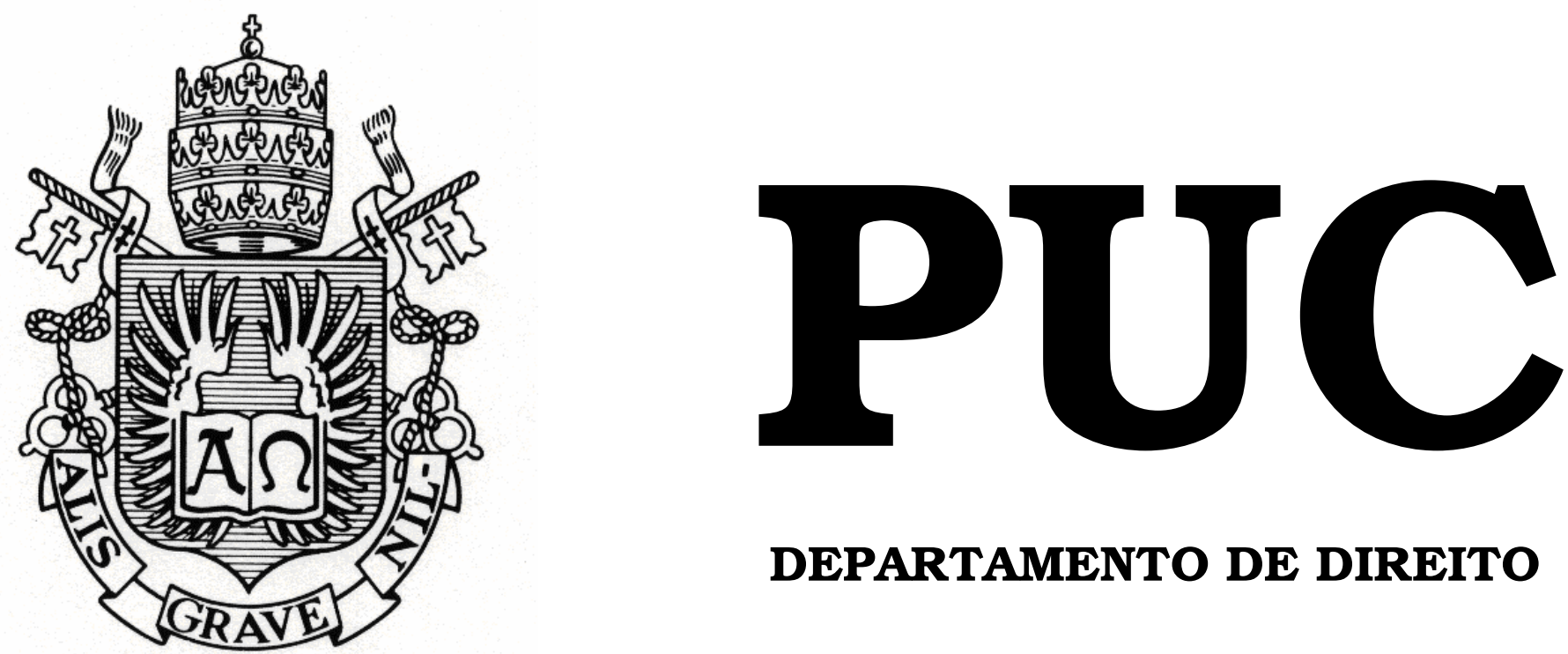

DEPARTAMENTO DE DIREITO

\title{
IMPOSTO DE RENDA SOBRE LUCROS AUFERIDOS POR FILIAIS, SUCURSAIS, COLIGADAS E CONTROLADAS NO EXTERIOR
}

por

PEDRO COSTA PRADO

ORIENTADORA: MARIA LÚCIA DE PAULA OLIVEIRA 2008.2

PONTIFÍCIA UNIVERSIDADE CATÓLICA DO RIO DE JANEIRO RUA MARQUÊS DE SÃO VICENTE, 225 - CEP 22453-900 RIO DE JANEIRO - BRASIL 


\title{
IMPOSTO DE RENDA SOBRE LUCROS AUFERIDOS POR FILIAIS, SUCURSAIS, COLIGADAS E CONTROLADAS NO EXTERIOR
}

\author{
por \\ PEDRO COSTA PRADO
}

Monografia apresentada ao Departamento de Direito da Pontifícia Universidade Católica do Rio de Janeiro (PUC-Rio) para a obtenção do Título de Bacharel em Direito.

Orientadora: Maria Lúcia de Paula Oliveira 
Dedicatória

Dedico este trabalho aos meus pais,

e amigos. 


\section{Agradecimentos}

Agradeço aos meus pais, que sempre me acompanharam e objetivaram me prover o melhor, com sabedoria e dedicação.

Agradeço aos amigos de faculdade, presentes em todas as fases da vida acadêmica e pessoal, sempre prontos a apoiar e descontrair nos momentos mais difíceis.

Agradeço aos amigos que fiz nos três escritórios de advocacia em que tive a oportunidade de vivenciar a prática jurídica. Sócios, advogados e estagiários que muito me ensinaram, e suportaram minhas discussões polêmicas sobre tudo o quanto envolvesse matéria de direito, economia, ciências ou outros saberes.

Agradeço aos excelentes professores que despertaram em mim o raciocínio jurídico apurado, me proporcionando o mais alto nível de conhecimento em universidade de excelência, cuja formação jurídica do curso de Direito é reconhecida e respeitada em todo o país.

Agradeço à minha orientadora, Professora Maria Lúcia, por ter se mostrado solícita, me instigando à produção deste trabalho.

Agradeço muito pelo amor e companheirismo daqueles que sempre estiveram bem próximos, e acompanharam e ainda acompanham todos os dias da minha vida. Sem vocês nada teria sido possível.

Pedro Costa Prado 


\section{Resumo}

O presente trabalho tem por objetivo analisar os aspectos da tributação - pelo Imposto de Renda das Pessoas Jurídicas - dos lucros auferidos por filiais, sucursais, sociedades coligadas e controladas no exterior. A idéia de se tributar a renda decorrente do lucro obtido em atividades exercidas no exterior está consubstanciada no princípio da universalidade, implementado no Brasil pela Lei n. ${ }^{\circ}$ 9.249/95. São abordados, aspectos de conexão dos princípios da territorialidade e da universalidade da tributação, com destaque para a evolução normativa do princípio da universalidade (Capítulos I e II).

Analisa-se, com base na legislação societária e tributária, os elementos necessários à determinação de como e quando tributar a renda obtida por meio de lucros auferidos no exterior. Para tanto, trabalha-se brevemente os conceitos de filial, sucursal, coligada e controlada, bem como as práticas contábeis adotadas pelas empresas, o conceito de renda e a regra-matriz do imposto de renda (Capítulos III e IV).

Por fim, aborda-se a questão relativa às coligadas e controladas sujeitas à ficção jurídica de disponibilidade da renda criada pela Medida Provisória $\mathrm{n}^{\mathrm{o}}$ 2.158-35/2001, e o atual posicionamento do Supremo Tribunal Federal no julgamento da Ação Direta de Inconstitucionalidade $n^{\circ}$ 2.588 que combate a referida Medida Provisória (Capítulos V e VI).

Palavras-Chave: Direito Tributário - Imposto de Renda - Princípio da Territorialidade e da Universalidade - Lucros no Exterior - Disponibilidade Econômica e Jurídica - Direito Societário - Contabilidade - Equivalência Patrimonial - Ficção Jurídica - Ação Direta de Inconstitucionalidade. 


\section{Sumário}

INTRODUÇÃ

Capítulo I - Conexão e Princípios de Tributação da Renda no

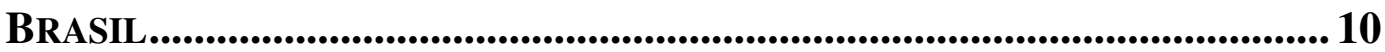

1.1. Princípio da territorialidade ............................................................... 11

1.2. Princípio da universalidade .................................................................13

1.2.1. Controlled Foreign Corporations - CFC Legislation........................15

Capítulo II - A Evolução normativa na ImPlementação do

PRINCÍPIO DA UNIVERSALIDADE NO BRASIL ................................................ 18

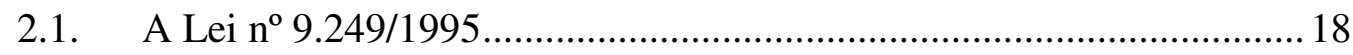

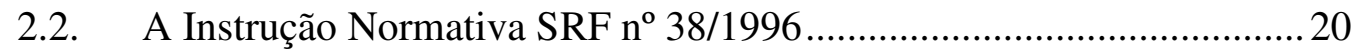

2.3. A Medida Provisória $\mathrm{n}^{\circ} 1.602$, convertida na Lei $\mathrm{n}^{\circ}$ 9.532/1997 ...........21

2.4. A Lei Complementar $\mathrm{n}^{\circ}$ 104/2001 ………………………...................22

2.5. A Medida Provisória $\mathrm{n}^{\circ}$ 2.158-35/2001 ………………......................24

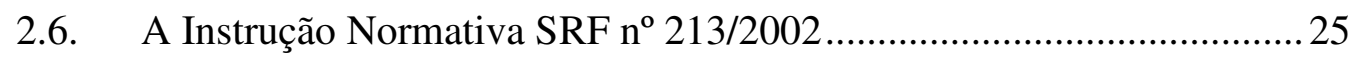

Capítulo III - Breves noções de Direito Societário e Práticas

CONTÁbEIS APLICADAS À TRIBUTAÇÃO DA RENDA NO EXTERIOR........... 28

3.1. Das sociedades controladas, coligadas, filiais e sucursais...................28

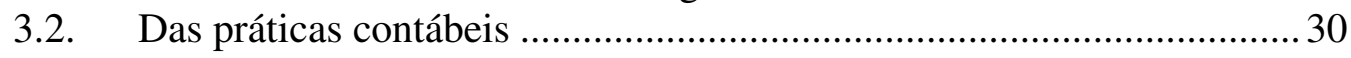

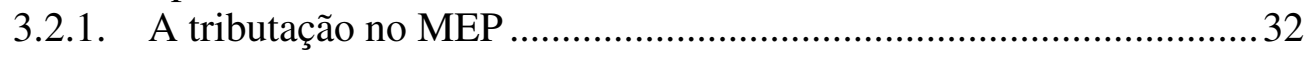

Capítulo IV - O Conceito de Renda e a Regra-Matriz do

IMPOSTO DE RENDA ......................................................................................35

4.1. Os critérios material e temporal da regra-matriz do imposto de renda .36

4.1.1. O conceito de renda como objeto do critério material......................37

4.1.2. O conceito de disponibilidade como objeto do critério temporal.....40

4.1.3. A disponibilidade econômica e jurídica ..........................................42

CAPÍTULO V - A FICÇÃo JURídica dO ART. 74 dA MP 2.158-35/2001 .. 44

CAPÍTULO VI - A ADI 2.588 E O ENTENDIMENTO do STF ...........................50

CAPÍTULO VII - CONCLUSÃO.....................................................................54

BIBLIOGRAFIA ......................................................................................................5 58 


\section{Lista de Abreviações}

ADI

$\operatorname{art}(\mathrm{s}) .:$

$\mathrm{CF} / 88$ :

CTN:

Des.:

IN

IR

IRPJ

LC

Lei das S.A.:

MEP

MP

Min.:

RE:

RESP:

Rel.:

SRF

STF:

STJ:

TRF:
Ação Declaratória de

Inconstitucionalidade

$\operatorname{artigo(s)}$

Constituição Federal de 1988

Código Tributário Nacional / Lei ${ }^{\circ}$

$5.172 / 1966$

Desembargador

Instrução Normativa

Imposto de Renda

Imposto de Renda das Pessoas

Jurídicas

Lei Complementar

Lei n ${ }^{\circ}$ 6.404/76 / Lei das Sociedades

por Ações

Método de Equivalência Patrimonial

Medida Provisória

Ministro(a)

Recurso Extraordinário

Recurso Especial

Relator

Secretaria da Receita Federal

Superior Tribunal Federal

Superior Tribunal de Justiça

Tribunal Regional Federal 


\section{INTRODUÇÃO}

A tributação dos lucros auferidos no exterior por filiais, sucursais, sociedades controladas e coligadas é tema de grande relevância no atual cenário de desenvolvimento econômico do Brasil. $\mathrm{O}$ crescimento da economia possui grande papel no aumento da arrecadação impostos, o que enseja o aprimoramento de um sistema tributário eficaz tanto na arrecadação quanto na viabilização de negócios e empresas.

O foco principal é o Imposto de Renda das Pessoas Jurídicas incidente nos lucros auferidos no exterior, pois o IRPJ é um dos impostos que implica grande carga tributária para as empresas, e, atualmente, todos os planejamentos societários e fiscais visam a desonerar, principalmente, a carga tributária decorrente do Imposto de Renda. Na econômica globalizada, o planejamento das empresas, tanto na expansão de suas atividades quanto na realização de investimentos, não se restringe às fronteiras do seu país de origem, o que leva uma sociedade ou grupo econômico a atuar em âmbito internacional.

O tema ganha importância no cenário nacional, visto que a implementação da tributação de lucros auferidos no exterior, pela Lei n. ${ }^{\circ}$ 9.249/95, atinge a todas as pessoas jurídicas sediadas no Brasil que possuam filiais ou sucursais em outros países, ou que possuam investimentos em sociedades estrangeiras caracterizando uma relação de controle ou coligação.

A evolução normativa demonstra que a lei oscilou quanto ao momento da tributação de lucros auferidos no exterior. Por vezes, optou por tratar de forma semelhante o momento da disponibilidade dos lucros auferidos por filiais e sucursais, e por coligadas e controladas; outras vezes 
optou por diferenciar o momento da disponibilidade desses lucros, de um lado, por filiais e sucursais, e de outro, por coligadas e controladas.

O problema surge no momento da tributação pelo IRPJ dos lucros auferidos no exterior, pois a matéria, atualmente disciplinada pela Lei $\mathrm{n}^{\mathbf{o}}$ 9.532/97, para filiais e sucursais, e pela Medida Provisória $\mathrm{n}^{\mathrm{o}}$ 2.15835/2008, para coligadas e controladas, determina, para fins ficais, que a disponibilidade dos lucros se dá quando do levantamento do balanço que os apurou. $\mathrm{O}$ grande questionamento cinge na possibilidade de a lei considerar ocorrido algo que efetivamente não ocorreu, tal qual a disponibilidade dos lucros auferidos no exterior. Trata-se portanto, de análise sobre o fato gerador do imposto de renda à luz da legislação infraconstitucional e da própria Constituição Federal.

Para explicar a controvérsia, e até mesmo, pensar uma solução, esta monografia se inicia com a distinção entre o princípio da territorialidade e o princípio da universalidade, abordando, inclusive, a intenção de se adotar uma forma de tributação mundial da renda.

Em seguida, destaca a distinção entre os conceitos de filial, sucursal, coligada e controlada, e a análise de aspectos contábeis das relações societárias. Munido da definição de "quem” está sujeito ao IRPJ e "qual lucro" se pretende tributar, passa à análise doutrinária do conceito de renda e dos elementos necessários à existência do fato gerador do Imposto de Renda.

Os capítulos V e VI são dedicados à exposição sobre a ficção jurídica criada pela Medida Provisória $\mathrm{n}^{\mathrm{o}}$ 2.158-35/2001, ao tratar da disponibilidade dos lucros auferidos exclusivamente por coligadas e controladas no exterior. O dispositivo da mencionada Medida Provisória, que trata da tributação de lucros no exterior, é atualmente, alvo de 
questionamento de constitucionalidade perante o Supremo Tribunal Federal.

Importa ressaltar, que o presente estudo tem por obejto apenas ao Imposto de Renda das Pessoas Jurídicas e sua tributação nas pessoas jurídicas sediadas no Brasil, e não leva em conta a existência de eventuais tratados internacionais para evitar bitributação da renda.

Por fím, o exame da questão é concluído com a consideração sobre os conceitos e formas de direito privado, os reflexos da atual sistemática da legislação, assim como as conseqüências contábeis, se propondo a uma visão crítica da atual sistemática de tributação da renda auferida no exterior, especialmente por sociedades coligadas e controladas, de acordo com parâmetros estabelecidos constitucionalmente. 


\section{Capítulo I - Conexão e Princípios de Tributação da Renda no BRASIL}

Os critérios de conexão têm a finalidade de relacionar os fatos que estão sujeitos à tributação de acordo com um vínculo previsto no sistema tributário que estabelece critérios e assegura a efetividade da norma tributária. ${ }^{1}$

Sobre o tema, Alberto Xavier define o elemento de conexão como:

"O elemento de conexão é o elemento da previsão normativa que, determinando a 'localização' de uma situação da vida num certo ordenamento tributário, tem como efeito típico determinar o âmbito de aplicação das leis desse ordenamento a essa mesma situação". ${ }^{2}$

Os critérios podem ser de natureza material ou subjetiva. Diz-se material quanto à localização da fonte efetiva da renda, e subjetiva quanto ao sujeito que aufere renda como residente, nacional ou domiciliado. ${ }^{3} \mathrm{Em}$ matéria de tributação pelo imposto de renda, podemos dizer que o critério de conexão material está ligado ao princípio da territorialidade e o critério de conexão subjetivo está ligado ao princípio da universalidade.

Assim, temos que os critérios de conexão compõem princípios regentes da tributação da renda, em especial quando se trata de tributação de lucros auferidos no exterior por sociedades sediadas no Brasil.

\footnotetext{
1 ALVES, Taciana Stanislau Afonso Bradley Alves. O Princípio da Renda Mundial no Direito Brasileiro. In: TÔRRES, Heleno Taveira (Coord.). Direito Tributário Internacional Aplicado. São Paulo: Quartier Latin, 2003. p. 607.

2 XAVIER, Alberto. Direito Tributário Internacional do Brasil. 6 ${ }^{\mathrm{a}}$ ed. Rio de Janeiro: Editora Forense, 2004. p. 252.

3 ALVES, Taciana Stanislau Afonso Bradley Alves. O Princípio da Renda Mundial no Direito Brasileiro. In: TÔRRES, Heleno Taveira (Coord.). Direito Tributário Internacional Aplicado. São Paulo: Quartier Latin, 2003. p. 607.
} 


\subsection{Princípio da territorialidade}

Para melhor analisar as implicações do sistema de tributação da renda obtida no exterior por pessoas jurídicas sediadas no Brasil, é interessante abordar a prévia sistemática adotada pela legislação tributária brasileira.

Antes da Lei $\mathrm{n}^{\circ} 9.249^{4}$, de 26 de dezembro de 1995, vigorava o princípio da territorialidade, no qual somente eram tributados os lucros auferidos no Brasil por fontes nacionais. Nesse sentido, importava o território, na acepção de espaço físico, onde a renda a ser tributada era produzida, ficando fora da incidência do Imposto de Renda os lucros obtidos em outros países que não no Brasil.

A territorialidade pressupõe a existência de um território e a idéia de vigência da lei em determinado espaço ${ }^{5}$ - território brasileiro submetido ao ordenamento jurídico brasileiro -, o que está também ligado ao poder de tributar do Estado, no exercício de sua soberania.

Nesse sentido, torna-se importante a composição estabelecida entre a noção de soberania e o princípio da territorialidade para que se visualize a limitação do poder de tributar do Estado, conforme leciona Heleno Tavares Tôrres:

"O poder de tributar, enquanto manifestação funcional da soberania na ordem
interna, é poder constituído, estabelecido constitucionalmente para gestão do
respectivo sistema tributário, apto, por via de seus princípios e normas, a
possibilitar entrada de receitas suficientes para o financiamento das atividades

\footnotetext{
${ }^{4}$ A Lei $n^{\circ}$ 9.249/95 deu início à reforma tributária de implementação do princípio da universalidade como veremos adiante.

5 "As leis são feitas para aplicação em determinada área territorial. Daí a extrema importância, para o jurista, da determinação do território" (TENÓRIO, Oscar. Direito internacional privado. $10^{\mathrm{a}}$ ed. v. 1. São Paulo: Freitas Bastos, 1970. p. 394.).
} 
inerentes ao Estado, com a aplicação dos tributos existentes, conforme os limites demarcados constitucionalmente para tanto". ${ }^{6}$

Logo, temos o território como critério de conexão para a tributação pelo Imposto de Renda, de modo que somente os rendimentos provenientes de fontes aqui localizadas estão sujeitos à tributação.

A territorialidade, como princípio de conexão, pautou a tributação da renda no sistema tributário brasileiro durante o período de 1922 a $1995 .{ }^{7}$ Nesse espaço de tempo, a legislação do imposto de renda sofreu alterações de forma a amadurecer e firmar a noção de territorialidade da tributação, inclusive ao dispor expressamente sobre o tratamento dado aos lucros auferidos no exterior. A exemplo disso, dispunha o artigo 205 do Decreto $\mathrm{n}^{\circ}$ 76.186, de 2 de setembro de 1975 (RIR/75), que regulamentou o artigo 63 da Lei $\mathrm{n}^{\circ}$ 4.506/64: "no caso de lucro derivado de atividade exercida parte no País e parte no exterior somente serão tributados os resultados produzidos no País". ${ }^{8}$ Fica claro, então, o intuito do legislador em separar, exatamente, qual renda que se pretendia tributar. Tal intenção está em perfeita consonância com a limitação do alcance da norma de direito interno tendo em vista a soberania dos Estados.

Esta breve exposição acerca do princípio da territorialidade tem o objetivo de conduzir ao raciocínio sobre a evolução da norma tributária com relação ao Imposto de Renda no Brasil, até os padrões atualmente vigentes. Transformações da ordem econômica há muito fizeram com que empresas e suas atividades não mais ficassem adstritas às fronteiras políticas do Estado. Sendo certo que muitas empresas possuem operações ou planejamentos

\footnotetext{
${ }^{6}$ TÔRRES, Heleno Taveira. Princípio da Territorialidade e Tributação de Não-Residentes no Brasil. Prestações de Serviços no Exterior. Fonte de Produção e Fonte do Pagamento. In: TÔRRES, Heleno Taveira (Coord.). Direito Tributário Internacional aplicado. São Paulo: Quartier Latin, 2003. p. 74-75.

${ }^{7}$ MATTOS, Aroldo Gomes de. Lucros, prejuízos e perdas, apurados no exterior. Tratamento tributário no Brasil. In: ROCHA, Valdir de Oliveira (Coord.). Grandes questões atuais do direito tributário. v. 6. São Paulo: Dialética, 2002. p. 9.

${ }^{8}$ PEDREIRA, José Luiz Bulhões. Imposto sobre a Renda: Pessoas Jurídicas. v. 1. Rio de Janeiro: Adcoas/Justec, 1979. p. 204.
} 
financeiros em nível internacional, para fins de tributação, o princípio da territorialidade ficou um tanto obsoleto.

\subsection{Princípio da universalidade}

O desenvolvimento da economia e a abertura dos mercados viabilizam de forma crescente a atuação das empresas em nível internacional. Então, nada mais razoável, principalmente para os Estados exportadores de capital, ${ }^{9}$ que se pretenda tributar os lucros produzidos além de seus territórios.

O princípio da universalidade, atualmente em vigor, foi introduzido pela Lei $\mathrm{n}^{\mathrm{o}}$ 9.249, de 26 de dezembro de 1995, que no caput do artigo 25, dispôs que "os lucros, rendimentos e ganhos de capital auferidos no exterior serão computados na determinação do lucro real das pessoas jurídicas correspondente ao balanço levantado em 31 de dezembro de cada ano".

Além de tributar os rendimentos obtidos no território brasileiro, independente da residência do beneficiário, importando tão somente o lugar da fonte efetiva de rendimentos (territorialidade), a lei estabeleceu o critério de conexão pessoal, importando não a fonte de rendimentos mas o local de residência do beneficiário (universalidade). Em outras palavras, a noção de renda mundial, proposta pelo princípio da universalidade, permite a tributação pelo Imposto de Renda dos lucros auferidos em qualquer lugar, contanto que o beneficiário seja residente no Brasil.

Heleno Taveira Tôrres defende que o princípio da universalidade não excluiu o princípio da territorialidade, visto que o primeiro seria complementar ao segundo. Nesse sentido, o princípio da universalidade

\footnotetext{
${ }^{9}$ TÔRRES, Heleno Taveira. Pluritributação internacional sobre as rendas de empresas. $2^{\mathrm{a}}$ ed.. São Paulo: Revista dos Tribunais, 2001. p. 86.
} 
abraça o princípio da territorialidade, pois constitui elemento possibilitador para uma tributação internacional, ${ }^{10}$ não deixando de existir a tributação pelo antigo critério de localização da fonte produtora da renda.

Não compartilha do mesmo entendimento, Alberto Xavier, que adotou posicionamento oposto ao definir que "a Lei $n^{\circ}$ 9.249/95 aboliu o princípio de territorialidade no que toca ao imposto de renda das pessoas jurídicas". ${ }^{11}$ Portanto, em seu entendimento, a instituição de uma tributação da renda mundial naturalmente se sobrepõe à idéia de tributação da renda local. Nesse sentido, conclui-se que o novo dispositivo legal simplesmente alargou a hipótese de incidência do imposto de renda, pois agora, os lucros e proventos de qualquer natureza obtidos no exterior passaram a integrar a sua base de cálculo.

A adoção do critério de tributação da renda mundial se justifica para suprimir distorções geradas pela aplicação do antigo critério territorial ao mundo contemporâneo. Empresas sediadas no Brasil, com operações dentro e fora do país, estavam em vantagem fiscal, em comparação às empresas que possuíam operações apenas dentro do país, pois parte de sua renda não era tributada pelo Imposto de Renda. Tal situação dissociava totalmente dos princípios constitucionais da isonomia e da capacidade contributiva, visto que a lei claramente excluía da incidência do imposto de renda, parte dos rendimentos de determinados contribuintes. ${ }^{12}$

Em linha com esse raciocínio, a universalidade da tributação da renda proporciona a redução do tratamento desigual aplicado aos

\footnotetext{
${ }^{10}$ TÔRRES, Heleno Taveira. Princípio da Territorialidade e Tributação de Não-Residentes no Brasil. Prestações de Serviços no Exterior. Fonte de Produção e Fonte do Pagamento. In: TÔRRES, Heleno Taveira (Coord.). Direito Tributário Internacional aplicado. São Paulo: Quartier Latin, 2003. p. 78.

${ }^{11}$ XAVIER, Alberto. Direito Tributário Internacional do Brasil. $6^{a}$ ed. Rio de Janeiro: Editora Forense, 2004. p. 436.

${ }^{12}$ TÔRRES, Heleno Taveira. Pluritributação internacional sobre as rendas de empresas. $2^{\mathrm{a}}$ ed. São Paulo: Revista dos Tribunais, 2001. p. 87.
} 
contribuintes, e também o combate a problemas de evasão fiscal internacional decorrentes de empresas com operações em "paraísos fiscais", ou conforme a lei os define, países com tributação favorecida. ${ }^{13}$

Neste ponto, a noção de renda mundial, a que se pretende ser tributada pelo princípio da universalidade, é medida para atingir um regime de transparência fiscal das sociedades empresárias, no combate ao uso elusivo $^{14}$ e à possibilidade de diferimento do pagamento do imposto, nas quais as sociedades controlam os fatos que produzem rendimentos, conforme veremos a seguir. ${ }^{15}$

\subsubsection{Controlled Foreign Corporations - CFC Legislation}

A CFC Legislation surgiu com a reforma Kennedy em 1962, nos Estados Unidos da América. Em linhas gerais, trata-se de um conjunto de normas de matéria fiscal, determinada a regular a tributação dos lucros auferidos por sociedades controladas sediadas em país diverso ao do domicílio dos sócios. ${ }^{16}$

\footnotetext{
${ }^{13}$ Considera-se país com tributação favorecida aquele "país que não tribute a renda ou que a tribute a alíquota máxima inferior a vinte por cento", conforme dispõe o caput do art. 24, da Lei $\mathrm{n}^{\circ}$ 9.430/96. No entanto, a Lei $n^{\circ} 11.727 / 2008$ ampliou essa definição ao introduzir o $\S^{\circ}$ ao referido artigo, com a seguinte redação: "Considera-se também país ou dependência com tributação favorecida aquele cuja legislação não permita o acesso a informações relativas à composição societária de pessoas jurídicas, à sua titularidade ou à identificação do beneficiário efetivo de rendimentos atribuídos a não residentes". Ainda sem ser atualizada, a IN/SRF n 188/2002, relaciona 53 países e localidades consideradas com tributação favorecida.

14 'Quanto à distinção entre 'evasão' e 'elusão' tributária, para uma parte da doutrina, esta seria possível de ser alcançada por meio de um critério cronológico, segundo o qual a 'evasão' se configuraria quando a conduta fosse praticada após a constituição do fato jurídico tributário, ou ao tempo deste; ao passo que, na 'elusão',o contribuinte organizaria suas atividades de modo a antecipar-se à própria fomarção do fato jurídico tributário, impedindo ou alterando sua ocorrência" (TÔRRES, Heleno Taveira. Direito Tributário e Direito Privado: autonomia privada, simulação, elusão tributária. São Paulo: Revista dos Tribunais, 2003. p. 189.).

${ }^{15}$ OKUMA, Alessandra. Da Tributação das Empresas Coligadas e Controladas. In: TÔRRES, Heleno Taveira (Coord.). Direito Tributário Internacional aplicado. v. 2. São Paulo: Quartier Latin, 2004. p. 508-509.

${ }^{16}$ XAVIER, Alberto. Direito Tributário Internacional do Brasil. $6^{\text {a }}$ ed. Rio de Janeiro: Editora Forense, 2004. p. 357.
} 
No planejamento fiscal das empresas, é comum que se realizem investimentos através da aquisição de participação societária, ou mesmo, constituição de uma pessoa jurídica em um país com tributação favorecida, com o objetivo de reduzir a carga fiscal, e diferir o pagamento do imposto por meio de pequenas distribuições de lucros. O objetivo da $C F C$ Legislation é, justamente, criar um regime de transparência fiscal, de modo a imputar aos sócios ou acionistas a obrigação tributária sobre os lucros auferidos pela sociedade estrangeira independente dos mesmos terem sido disponibilizados. $^{17}$

A aplicação da CFC legislation depende de requisitos dentre os quais: a presença de relação de controle, a ausência de propósito negocial, ou a residência em país com tributação favorecida. Heleno Taveira Torres esclarece que:

\footnotetext{
"As formas de uso indevido de sociedades controladas no exterior (SCE), são claramente identificadas quando se verifica que:

1. um residente é controlador ou possui uma grande participação em uma sociedade localizada no estrangeiro;

2. o regime fiscal do país de residência dessa sociedade estrangeira é mais vantajoso que o do país onde residem os acionistas;

3. a sociedade distribui só uma pequena parte do seu rendimento sob a forma de dividendos, ou não distribui dividendos;

4. a obtenção dos rendimentos prescinde de desenvolvimento de efetivas atividades empresariais no país onde a sociedade controlada encontra-se constituída". ${ }^{18}$
}

Fica clara a rigidez de que é dotada a $C F C$ Legislation, pois ela não se aplica a qualquer caso. A esse respeito, ensina Alberto Xavier:

\begin{abstract}
"Deve-se dizer que o sistema de transparência internacional, conducente a uma tributação extra territorial ou de universalidade alargada não é adotado em nenhum país como modalidade de tributação normal da renda externa das pessoas
\end{abstract}

\footnotetext{
${ }^{17}$ TÔRRES, Heleno Taveira. Pluritributação internacional sobre as rendas de empresas. $2^{\mathrm{a}}$ ed.. São Paulo: Revista dos Tribunais, 2001. p. 207-208.

${ }_{18}$ TÔRRES, Heleno Taveira. Direito Tributário Internacional: Planejamento tributário e operações transnacionais. São Paulo: Revista dos Tribunais, 2001. p. 127.
} 
jurídicas, mas tão-somente como modalidade excepcional tendente a evitar 'abusos' ou 'evasões"', ${ }^{19}$

Pelo exposto, há muito em comum ao princípio da universalidade implementado no Brasil pela Lei no 9.249/95. No entanto, a lei brasileira pretendeu sua aplicação indistintamente a todas as pessoas jurídicas que de alguma forma auferissem lucros no exterior - fosse por meio de coligadas, controladas, filais ou sucursais -, o que não compartilha a idéia contida na CFC Legislation.

${ }^{19}$ XAVIER, Alberto. Direito Tributário Internacional do Brasil. $5^{\text {a }}$ ed. Rio de Janeiro: Editora Forense, 2002. p. 351. 


\section{Capítulo II - A Evolução Normativa na Implementação do PrincíPIO da Universalidade no Brasil}

\subsection{A Lei no $9.249 / 1995$}

Como já mencionado, o princípio da universalidade da renda foi introduzido pelo artigo 25 da Lei $\mathrm{n}^{\circ}$ 9.249, de 26 de dezembro de 1995, que passou a ter vigência a partir de $1^{\circ}$ de janeiro de 1996. O referido dispositivo determinava que os lucros obtidos por sociedades controladas e coligadas sediadas no exterior, bem como por filiais e sucursais, deveriam ser tributados ao final do ano-calendário em que foram apurados, quando do levantamento do balanço das referidas sociedades.

$\mathrm{Na}$ sua redação final, os comandos contidos nos parágrafos e incisos do artigo 25 faziam pequenas distinções quanto ao tipo da relação societária, de modo a adequar as práticas contábeis em cada caso. Vejamos:

\footnotetext{
“Art. 25. Os lucros, rendimentos e ganhos de capital auferidos no exterior serão computados na determinação do lucro real das pessoas jurídicas correspondente ao balanço levantado em 31 de dezembro de cada ano.

(...)

$\S 2^{\circ}$ Os lucros auferidos por filiais, sucursais ou controladas, no exterior, de pessoas jurídicas domiciliadas no Brasil serão computados na apuração do lucro real com observância do seguinte:

I - as filiais, sucursais e controladas deverão demonstrar a apuração dos lucros que auferirem em cada um de seus exercícios fiscais, segundo as normas da legislação brasileira;

II - os lucros a que se refere o inciso I serão adicionados ao lucro líquido da matriz ou controladora, na proporção de sua participação acionária, para apuração do lucro real;

III - se a pessoa jurídica se extinguir no curso do exercício, deverá adicionar ao seu lucro líquido os lucros auferidos por filiais, sucursais ou controladas, até a data do balanço de encerramento;

IV - as demonstrações financeiras das filiais, sucursais e controladas que embasarem as demonstrações em Reais deverão ser mantidas no Brasil pelo prazo previsto no art. 173 da Lei no 5.172 , de 25 de outubro de 1966.
}

$\S 3^{\circ}$ Os lucros auferidos no exterior por coligadas de pessoas jurídicas domiciliadas no Brasil serão computados na apuração do lucro real com observância do seguinte: 
I - os lucros realizados pela coligada serão adicionados ao lucro líquido, na proporção da participação da pessoa jurídica no capital da coligada;

II - os lucros a serem computados na apuração do lucro real são os apurados no balanço ou balanços levantados pela coligada no curso do período-base da pessoa jurídica;

III - se a pessoa jurídica se extinguir no curso do exercício, deverá adicionar ao seu lucro líquido, para apuração do lucro real, sua participação nos lucros da coligada apurados por esta em balanços levantados até a data do balanço de encerramento da pessoa jurídica;

IV - a pessoa jurídica deverá conservar em seu poder cópia das demonstrações financeiras da coligada" (não grifado no original).

Assim, a tributação recaía sobre a correspondente pessoa jurídica domiciliada no Brasil, uma vez que a Lei determinava que os lucros gerados no exterior deveriam ser adicionados ao lucro líquido da sociedade brasileira, na proporção de sua participação societária, para apuração do Lucro Real a ser tributado pelo Imposto de Renda.

A esse respeito, Alberto Xavier pondera não se tratar de uma simples universalidade da tributação da renda, mas de um regime de transparência fiscal internacional que vai além disso.

"É importante salientar que este sistema de tributação vai mais longe que o princípio da universalidade, na pureza dos seus contornos, pois manda adicionar ao lucro da sociedade domiciliada no Brasil, a totalidade do lucro obtido pelas controladas ou coligadas no exterior, na proporção da participação no capital social destas, ainda que tais lucros tenham sido integralmente retidos e não distribuídos. Assim sendo, o imposto brasileiro atingiria renda de titularidade jurídica de sociedades estrangeiras independentes. Trata-se, portanto, de um sistema de 'universalidade ampliada' ou de tributação extraterritorial ou ultraterritorial".

Dessa forma, a sociedade controladora, matriz ou coligada, estabelecida no Brasil, estaria sujeita à tributação pelo Imposto de Renda incidente sobre os lucros obtidos por suas sociedades no exterior, independente de tais lucros terem sido distribuídos. À época, tais

\footnotetext{
${ }^{20}$ XAVIER, Alberto. Direito Tributário Internacional do Brasil. $6^{\text {a }}$ ed. Rio de Janeiro: Editora Forense, 2004. p. 439.
} 
disposições violavam frontalmente o conceito de renda disponível previsto no artigo 43 do Código Tributário Nacional. ${ }^{21}$

Portanto, definido o fato gerador do Imposto de Renda como a aquisição da disponibilidade econômica ou jurídica da renda, não poderia a Lei $n^{\circ}$ 9.249/95 pretender a tributação da renda não disponível, como ocorria na hipótese prevista.

\subsection{A Instrução Normativa SRF no 38/1996}

Em 27 de junho de 1996, foi editada pela Secretaria da Receita Federal a Instrução Normativa $n^{\circ} 38$, versando sobre a tributação de lucros, rendimentos e ganhos de capital auferidos no exterior por pessoas jurídicas domiciliadas no Brasil. Dentre outras providências, a mencionada Instrução Normativa, em seu artigo $2^{\circ}{ }^{22}$ determinou as hipóteses em que os lucros auferidos por sociedades coligadas e controladas sediadas no exterior, seriam considerados disponibilizados ou distribuídos para as sociedades investidoras brasileiras, estando sujeitos à tributação pelo IRPJ.

A Instrução Normativa tenta, sem sucesso, sanar as ilegalidades e inconstitucionalidades da Lei $\mathrm{n}^{\circ}$ 9.249/95, ao determinar, expressamente, que os lucros provenientes do exterior só serão tributados depois de disponibilizados, e que só são considerados disponibilizados os lucros "pagos ou creditados" às sociedades investidoras brasileiras. Ressalte-se

\footnotetext{
${ }^{21}$ Art. 43: "O imposto, de competência da União, sobre a renda e proventos de qualquer natureza tem como fato gerador a aquisição da disponibilidade econômica ou jurídica:

I - de renda, assim entendido o produto do capital, do trabalho ou da combinação de ambos;

II - de proventos de qualquer natureza, assim entendidos os acréscimos patrimoniais não compreendidos no inciso anterior".

${ }^{22}$ Art. $2^{\circ}$ : "Os lucros auferidos no exterior, por intermédio de filiais, sucursais, controladas ou coligadas serão adicionados ao lucro líquido do período-base, para efeito de determinação do lucro real correspondente ao balanço levantado em 31 de dezembro do ano-calendário em que tiverem sido disponibilizados.

$\S 1^{\circ}$ Consideram-se disponibilizados os lucros pagos ou creditados à matriz, controladora ou coligada, no Brasil, pela filial, sucursal, controlada ou coligada no exterior".
} 
que, as instruções normativas editadas pela Secretaria da Receita Federal são normas tributárias de caráter secundário que não possuem força de lei, de modo que não podem restringir ou alterar disposição estabelecida em lei, sob pena de afronta à Constituição Federal.

\subsection{A Medida Provisória no 1.602, convertida na Lei no 9.532/1997}

Em 14 de novembro de 1997, foi editada a Medida Provisória $\mathrm{n}^{\mathrm{o}}$ 1.602, pouco menos de um mês depois, convertida na Lei $n^{\circ} 9.532$, de 10 de dezembro de 1997, sem que tivesse sofrido alteração substancial. A nova disposição legal trazia a idéia contida na IN/SRF nº 38/96, e determinava que os lucros auferidos no exterior somente seriam adicionados ao lucro líquido da sociedade investidora brasileira, depois de disponibilizados. Porém, o $\S 1^{\circ}$ do artigo $1^{\circ}$, da Lei $n^{\circ} 9.532 / 97$, criou duas hipóteses ao determinar quando tais lucros seriam considerados disponibilizados. A saber: os lucros auferidos no exterior seriam considerados disponibilizados (i) na data do balanço em que foram apurados, no caso de filial ou sucursal, ou (ii) na data do pagamento ou do crédito em conta, no caso de controlada ou coligada. $^{23}$

Notadamente, a referida Lei teve o intuito de sanar as ilegalidades contidas no artigo 25 da Lei $n^{\circ}$ 9.249/95, conforme se infere da Exposição de Motivos da MP $\mathrm{n}^{\mathrm{o}}$ 1.602/97, em que foi declarado pelo Ministro da Fazenda:

\footnotetext{
23 Art. $1^{\circ}$ : "Os lucros auferidos no exterior, por intermédio de filiais, sucursais, controladas ou coligadas serão adicionados ao lucro líquido, para determinação do lucro real correspondente ao balanço levantado no dia 31 de dezembro do ano-calendário em que tiverem sido disponibilizados para a pessoa jurídica domiciliada no Brasil".

" $\$ 1^{\circ}$ Para efeito do disposto neste artigo, os lucros serão considerados disponibilizados para a empresa no Brasil:

a) no caso de filial ou sucursal, na data do balanço no qual tiverem sido apurados;

b) no caso de controlada ou coligada, na data do pagamento ou do crédito em conta representativa de obrigação da empresa no exterior".
} 
"O art. $1^{\circ}$ do Projeto refere-se às hipóteses em que os lucros auferidos por filiais, sucursais, controladas ou coligadas de empresas brasileiras no exterior são considerados disponíveis para a investidora no Brasil.

Esta definição é importante do ponto de vista tributário, tendo em vista que o fato gerador do imposto de renda, na hipótese desses rendimentos, ocorre com a disponibilização dos lucros auferidos no exterior".

Nesse sentido, a nova legislação obteve sucesso em regular a matéria com relação à tributação das coligadas e controladas. As disposições do $\S 1^{\circ}$, alínea $b$, da Lei $\mathrm{n}^{\circ} 9.532 / 97$, estavam em perfeita harmonia com o conceito de disponibilidade da renda, ou seja, com o fato gerador do IRPJ. Contudo, não cessaram as alterações na legislação tributária concernentes à incidência do IR sobre lucros auferidos no exterior por coligadas e controladas.

\subsection{A Lei Complementar no $104 / 2001$}

Em continuidade às sucessivas alterações, no que diz respeito à tributação de lucros auferidos no exterior, a $\operatorname{LC~}^{\circ}$ 104, de 10 de janeiro de 2001, introduziu dois novos parágrafos ao artigo 43 do CTN, de modo a delegar ao legislador ordinário, a competência para determinar, exatamente, quando seriam considerados disponibilizados os lucros auferidos no exterior. Assim ficou consolidado o dispositivo que trata do fato gerador do Imposto de Renda:

\footnotetext{
"Art. 43. O imposto, de competência da União, sobre a renda e proventos de qualquer natureza tem como fato gerador a aquisição da disponibilidade econômica ou jurídica:

I - de renda, assim entendido o produto do capital, do trabalho ou da combinação de ambos;

II - de proventos de qualquer natureza, assim entendidos os acréscimos patrimoniais não compreendidos no inciso anterior.

§ 1o A incidência do imposto independe da denominação da receita ou do rendimento, da localização, condição jurídica ou nacionalidade da fonte, da origem e da forma de percepção.

§ 20 Na hipótese de receita ou de rendimento oriundos do exterior, a lei estabelecerá as condições e o momento em que se dará sua disponibilidade, para fins de incidência do imposto referido neste artigo" (grisou-se).
} 
Importa ressaltar, que a despeito do que dispõe o artigo 43, caput e $\$ 2^{\circ}$, do CTN, a lei não pode simplesmente ignorar hipóteses fáticas para criar situações existentes apenas no mundo jurídico. ${ }^{24}$ Isso quer dizer que o ato normativo estará sempre restrito ao significado da palavra, neste caso, da "disponibilidade", que não admite maiores variações a respeito da determinação de sua ocorrência. Quanto a este tema, Ricardo Mariz de Oliveira esclarece que:

\begin{abstract}
"Às disponibilidades a que alude o 'caput' do art. 43, das quais participa a disponibilidade a que se refere o $\$ 2^{\circ}$ (esta não é uma disponibilidade autônoma ou diferente daquelas) não se constituem em criações autoritárias da lei, mas, sim, são reflexos da realidade fática (disponibilidade econômica) ou jurídica (disponibilidade jurídica) que a lei tributária encontra na realidade fenomênica sobre a qual ela atua". ${ }^{25}$
\end{abstract}

A leitura isolada do texto do $\$ 2^{\circ}$, do dispositivo em pauta, abre caminho para que o legislador ordinário trabalhe o conceito de "disponibilidade" como bem entender, o que pode contribuir para a produção de noções distorcidas da realidade fática. Vale lembrar que a melhor técnica de interpretação da lei sugere que a leitura dos parágrafos deve ser feita em conjunto com a sua norma regente, ou seja, o caput do artigo, bem como manda a Lei Complementar no 95/1998. ${ }^{26}$

\footnotetext{
${ }^{24}$ Conforme voto do Min. Luiz Galloti, citado pelo Min. Marco Aurélio em voto no RE ${ }^{\circ}$ 150.764/PE: "Como sustentei muitas vezes, ainda no Rio, se a lei pudesse chamar de compra o que não é compra, de importação o que não é importação, de exportação o que não é exportação, de renda o eu não é renda, ruiria todo o sistema tributário inscrito na Constituição" (transcrição na folha de rosto da ADI no 2588, proposta pela Confederação Nacional da Indústria).

${ }^{25}$ OLIVEIRA, Ricardo Mariz de. O Conceito de Renda - Inovação do art. 43 do CTN pela Lei Complementar $n^{\circ} 104$ (a Questão da Disponibilidade sobre Lucros de Coligadas e Controladas no Exterior). Revista Dialética de Direito Tributário. São Paulo, n. 73, out. 2001. p. 113-114.

${ }^{26}$ Art. 11: "As disposições normativas serão redigidas com clareza, precisão e ordem lógica, observadas, para esse propósito, as seguintes normas:

(...)

III - para a obtenção de ordem lógica:

(...)

c) expressar por meio dos parágrafos os aspectos complementares à norma enunciada no caput do artigo e as exceções à regra por este estabelecida".
} 


\subsection{A Medida Provisória no 2.158-35/2001}

Em linha com a alteração implementada pela Lei Complementar $n^{\circ}$ 104/2001, dentre outras providências, a Medida Provisória $n^{\circ} 2.158-35,{ }^{27}$ de 24 de agosto de 2001, em seu artigo 74, decorridos quase 6 anos, retomou a idéia primitiva contida nos $\S \S 2^{\circ}$ e $3^{\circ}$ do art. 25 , da Lei $n^{\circ} 9.249 / 95$, ao dispor que:

"Art. 74. Para fim de determinação da base de cálculo do imposto de renda e da CSLL, nos termos do art. 25 da Lei no 9.249, de 26 de dezembro de 1995, e do art. 21 desta Medida Provisória, os lucros auferidos por controlada ou coligada no exterior serão considerados disponibilizados para a controladora ou coligada no Brasil na data do balanço no qual tiverem sido apurados, na forma do regulamento.

Parágrafo único. Os lucros apurados por controlada ou coligada no exterior até 31 de dezembro de 2001 serão considerados disponibilizados em 31 de dezembro de 2002, salvo se ocorrida, antes desta data, qualquer das hipóteses de disponibilização previstas na legislação em vigor".

Por sua vez, assim dispõe o artigo 21 da Medida Provisória em comento:

"Art. 21. Os lucros, rendimentos e ganhos de capital auferidos no exterior sujeitam-se à incidência da CSLL, observadas as normas de tributação universal de que tratam os arts. 25 a 27 da Lei $n^{\circ} 9.249$, de 1995 , os arts. 15 a 17 da Lei ${ }^{\circ}$ 9.430, de 1996, e o art. $1^{\circ}$ da Lei ${ }^{\circ} 9.532$, de 1997.

Parágrafo único. O saldo do imposto de renda pago no exterior, que exceder o valor compensável com o imposto de renda devido no Brasil, poderá ser compensado com a CSLL devida em virtude da adição, à sua base de cálculo, dos lucros oriundos do exterior, até o limite acrescido em decorrência dessa adição".

Note-se que o conteúdo normativo do artigo 74, qual seja, o momento em que se dá a disponibilidade dos lucros, foi direcionado exclusivamente às coligadas e controladas estrangeiras, excluídas as filiais e sucursais que já se sujeitavam, por força do art. $1^{\circ}, \S 1^{\circ}$, alínea $a$, da Lei $\mathrm{n}^{\mathrm{o}}$ 9.532/97, ao regime semelhante de disponibilização da renda ora proposto pela MP.

${ }^{27} \mathrm{O}$ preceito do artigo 74 foi introduzido na $34^{\mathrm{a}}$ edição da Medida Provisória $\mathrm{n}^{\mathrm{o}} 2.158$ e mantido na última versão $\left(35^{\mathrm{a}}\right)$ de 24 de agosto de 2001, atualmente vigente nos termos do artigo $2^{\mathrm{a}}$ da Emenda Constitucional n ${ }^{\circ} 32$, de 11 de setembro de 2001. 
Por meio da referida Medida Provisória, a Presidência da República fez uso do permissivo no $\S 2^{\circ}$ do artigo 43 , do CTN, incluído pela LC n 104/2001, anteriormente comentada. A legislação pátria restou então firmada, no sentido de determinar a tributação pelo IRPJ dos lucros de coligadas e controladas, auferidos no exterior, independente de serem distribuídos, pagos ou creditados à sociedade investidora brasileira.

\subsection{A Instrução Normativa SRF no 213/2002}

Como de praxe, a Secretaria da Receita Federal expediu a Instrução Normativa SRF no 213, de 7 de outubro de 2002, que veio a regulamentar questões técnicas decorrentes da sistemática de tributação da renda adotada pela legislação brasileira.

A definição do objeto do regime de tributação vem expressa no artigo $1^{\circ}$ e seus parágrafos da seguinte forma:

\footnotetext{
"Art. $1^{\circ}$ Os lucros, rendimentos e ganhos de capital auferidos no exterior, por pessoa jurídica domiciliada no Brasil, estão sujeitos à incidência do imposto de renda das pessoas jurídicas (IRPJ) e da contribuição social sobre o lucro líquido (CSLL), na forma da legislação específica, observadas as disposições desta Instrução Normativa.
}

$\S 1^{\circ}$ Os lucros referidos neste artigo são os apurados por filiais e sucursais da pessoa jurídica domiciliada no Brasil e os decorrentes de participações societárias, inclusive em controladas e coligadas.

$\S 2^{\circ}$ Os rendimentos e ganhos de capital a que se refere este artigo são os auferidos no exterior diretamente pela pessoa jurídica domiciliada no Brasil.

$\S 3^{\circ}$ A pessoa jurídica domiciliada no Brasil que auferir lucros, rendimentos e ganhos de capital oriundos do exterior, objeto das normas desta Instrução Normativa, está obrigada ao regime de tributação com base no lucro real.

$\S 4^{\circ}$ Os lucros de que trata este artigo serão adicionados ao lucro líquido, para determinação do lucro real e da base de cálculo da CSLL da pessoa jurídica no Brasil, integralmente, quando se tratar de filial ou sucursal, ou proporcionalmente à sua participação no capital social, quando se tratar de controlada ou coligada.

$\S 5^{\circ}$ Para efeito de tributação no Brasil, os lucros serão computados na determinação do lucro real e da base de cálculo da CSLL, de forma 
individualizada, por filial, sucursal, controlada ou coligada, vedada a consolidação dos valores, ainda que todas as entidades estejam localizadas em um mesmo país, sendo admitida a compensação de lucros e prejuízos conforme disposto no $\S 5^{\circ}$ do art. $4^{\circ}$ desta Instrução Normativa.

$\S 6^{\circ}$ Os resultados auferidos por intermédio de outra pessoa jurídica, na qual a filial, sucursal, controlada ou coligada, no exterior, mantenha qualquer tipo de participação societária, ainda que indiretamente, serão consolidados no balanço da filial, sucursal, controlada ou coligada para efeito de determinação do lucro real e da base de cálculo da CSLL da beneficiária no Brasil.

$\S 7^{\circ}$ Os lucros, rendimentos e ganhos de capital de que trata este artigo a serem computados na determinação do lucro real e da base de cálculo de CSLL, serão considerados pelos seus valores antes de descontado o tributo pago no país de origem.

$\S 8^{\circ}$ Os rendimentos e os ganhos de capital, decorrentes de aplicações ou operações efetuadas no exterior, integrarão os resultados da pessoa jurídica domiciliada no Brasil, e as perdas reconhecidas nesses resultados são indedutíveis e devem ser adicionadas para determinação do lucro real e da base de cálculo da CSLL".

Consolidando a tributação pelo IRPJ dos lucros auferidos no exterior, o artigo $2^{\circ}$, caput, trata da disponibilização dos lucros sem maiores definições. Limita-se a dizer o seguinte:

\footnotetext{
"Art. $2^{\circ}$ Os lucros auferidos no exterior, por intermédio de filiais, sucursais, controladas ou coligadas serão computados para fins de determinação do lucro real e da base de cálculo da CSLL no balanço levantado em 31 de dezembro do ano-calendário em que tiverem sido disponibilizados para a pessoa jurídica domiciliada no Brasil”.
}

Vale lembrar, que presente Instrução Normativa foi editada à luz do que dispõe a Medida Provisória $\mathrm{n}^{\mathrm{o}}$ 2.158-35/2001. Sendo assim, a disposição do artigo $2^{\circ}$ de que os lucros auferidos no exterior serão computados para apuração do lucro real no balanço levantado - pela sociedade brasileira - em 31 de dezembro do ano em que foram disponibilizados, deve ser interpretada de acordo com a mencionada Medida Provisória, que determina que a disponibilização ocorre na data do levantamento do balanço - da sociedade estrangeira - que apura os lucros no exterior. 
A Instrução Normativa em nada inova nesse ponto, pois cria um dispositivo que independe do conceito de disponibilização dos lucros, matéria tratada pela legislação. No entanto, o artigo $7^{\circ}$ da Instrução Normativa em tela, trouxe nova hipótese de tributação ao dispor que a contrapartida do ajuste do valor do investimento no exterior pelo método de equivalência patrimonial é contabilizada na apuração do lucro da sociedade brasileira. $^{28}$ Tal previsão não encontra respaldo legal conforme veremos de forma mais detalhada adiante.

\footnotetext{
${ }^{28}$ Art. $7^{\text {o: }}$ "A contrapartida do ajuste do valor do investimento no exterior em filial, sucursal, controlada ou coligada, avaliado pelo método da equivalência patrimonial, conforme estabelece a legislação comercial e fiscal brasileira, deverá ser registrada para apuração do lucro contábil da pessoa jurídica no Brasil’.
} 


\section{Capítulo III - Breves Noções de Direito Societário e Práticas Contábeis aplicadas À Tributação DA RENDA NO EXTERIOR}

Para melhor esclarecer as implicações práticas dos dispositivos legais a que estão submetidas as sociedades estabelecidas no Brasil, é importante abordar alguns conceitos e formas das relações societárias, bem como os padrões de contabilidade geralmente aceitos.

\subsection{Das sociedades controladas, coligadas, filiais e sucursais}

Os conceitos de sociedades "controladas" e "coligadas" estão ligados à relação de investimento que uma sociedade guarda com outra. Tais noções estão claramente definidas na Lei $\mathrm{n}^{\mathrm{o}} \quad 6.404 / 1976,{ }^{29}$ mais precisamente no artigo 243 e seus parágrafos:

"Art. 243. O relatório anual da administração deve relacionar os investimentos da companhia em sociedades coligadas e controladas e mencionar as modificações ocorridas durante o exercício.

$\S 1^{\circ}$ São coligadas as sociedades quando uma participa, com $10 \%$ (dez por cento) ou mais, do capital da outra, sem controlá-la.

$\S 2^{\circ}$ Considera-se controlada a sociedade na qual a controladora, diretamente ou através de outras controladas, é titular de direitos de sócio que lhe assegurem, de modo permanente, preponderância nas deliberações sociais e o poder de eleger a maioria dos administradores.

$\S 3^{\circ}$ A companhia aberta divulgará as informações adicionais, sobre coligadas e controladas, que forem exigidas pela Comissão de Valores Mobiliários" (grifouse).

É evidente, portanto, que a participação societária detida pela sociedade brasileira em sociedade estrangeira constitui fator determinante, mas não único, para a caracterização da sociedade estrangeira como

\footnotetext{
${ }^{29}$ Há também definição semelhante nos artigos 1.097 a 1.100 da Lei n ${ }^{\circ}$ 10.406/2002 (Código Civil de 2002).
} 
controlada ou coligada. Decerto que, ambas, controlada ou coligada, são sociedades das quais um percentual do seu capital social é tido como um investimento realizado pela sociedade brasileira.

No entanto, à luz do que dispõe o artigo 74 da MP nº 2.158-35/2001, não há distinção, para efeitos de tributação, entre os lucros auferidos por controladas ou coligadas. Isso porque, coligada e controlada divergem apenas no percentual de participação detido e quanto ao poder de controle ${ }^{30}$ a que uma sociedade está submetida pela sua investidora.

Melhor sorte não assiste aos conceitos de filial e sucursal, que não encontram definições claras no texto da legislação societária ou civil. Cabe então à doutrina o papel definir tais conceitos.

\section{Waldemar Ferreira comenta sobre sucursal:}

"a despeito de serem ambos (estabelecimento principal e sucursal) centros da vida societária e apresentarem-se idênticamente organizados, salienta-se esta (sucursal) por nota distintiva inconfundível. Ela opera subordinadamente, relativamente ao estabelecimento principal, do qual recebe ordens e diretrizes". ${ }^{31}$

Por conseguinte, conceitua filial da seguinte forma:

"Caracteriza-se a filial por ser estabelecimento congênere da matriz, em que se realizem as mesmas operações desta, a revelar-se por instalação material distinta,

\footnotetext{
${ }^{30}$ A Lei das S.A. define acionista controlador em seu artigo 116. Vejamos:

Art. 116: "Entende-se por acionista controlador a pessoa, natural ou jurídica, ou o grupo de pessoas vinculadas por acordo de voto, ou sob controle comum, que:

a) é titular de direitos de sócio que lhe assegurem, de modo permanente, a maioria dos votos nas deliberações da assembléia-geral e o poder de eleger a maioria dos administradores da companhia;e,

b) usa efetivamente seu poder para dirigir as atividades sociais e orientar o funcionamento dos órgãos da companhia". Sobre o tema, José Edwaldo Tavares Borba leciona: "Controla uma sociedade quem detém o poder de comandá-la, escolhendo os seus administradores e definindo as linhas básicas de sua atuação. Esse poder funda-se no voto e se manifesta, basicamente, nas assembléias-gerais, onde se exerce de forma ostensiva. Mas, mesmo fora das assembléias, continua a exercer, de forma indireta, face à dependência em que se colocam os administradores diante do titular do poder de controle" (BORBA, José Edwaldo Tavares. Direito Societário. $7^{\mathrm{a}}$ ed. Rio de Janeiro: Renovar, 2001. p. 314.).

31 FERREIRA, Waldemar. Tratado de Direito Comercial: O Estatuto do Estabelecimento e a Emprêsa Mercantil. v. 6. São Paulo: Saraiva, 1962. p. 36.
} 
mas sem nenhuma autonomia, por subordinada àquela, dirigida por gerente ou preposto daquela". ${ }^{32}$

Então, podemos concluir que por filial ou sucursal não se entende uma nova pessoa jurídica, mas tão somente uma extensão operacional daquela tida como matriz ou estabelecimento principal, com o propósito de facilitar negócios específicos em determinada localidade. ${ }^{33}$

A Lei $\mathrm{n}^{\circ}$ 9.532/97, ao colocar de um lado filiais e sucursais, e de outro, coligadas e controladas, a fim de considerar a disponibilização da renda auferida por elas no exterior, pretendeu diferenciar aquilo que constitui uma relação entre pessoas jurídicas independentes - controladora brasileira e controlada estrangeira, e coligada brasileira e coligada estrangeira - e uma mera extensão da atuação de uma única pessoa jurídica - matriz brasileira e sua filial ou sucursal estrangeira.

\subsection{Das práticas contábeis}

As sociedades que possuem participações em outras sociedades devem manter na sua contabilidade o valor dessas participações, para refletir com fidelidade a sua situação patrimonial quando do encerramento do balanço. Cumpre esclarecer que são adotados dois métodos para contabilizar essas participações societárias nas contas de investimentos: $:^{34}$ método de custo e método de equivalência patrimonial ("MEP”).

\footnotetext{
32 FERREIRA, Waldemar. Tratado de Direito Comercial: O Estatuto do Estabelecimento e a Emprêsa Mercantil. v. 6. São Paulo: Saraiva, 1962. p. 40.

${ }^{33}$ WALD, Arnoldo. In: TEIXEIRA, Sálvio de Figueired (Coord.). Comentários ao Novo Código Civil: Livro II - Do Direito de Empresa, arts. 966 a 1.195. v. 14. Rio de Janeiro: Editora Forense, 2005. p. 140.

${ }^{34}$ Art. 179: "As contas serão classificadas do seguinte modo:

(...)

III - em investimentos: as participações permanentes em outras sociedades e os direitos de qualquer natureza, não classificáveis no ativo circulante, e que não se destinem à manutenção da atividade da companhia ou da empresa".
} 
A legislação comercial determina quando um ou outro método deve ser utilizado para a avaliação na conta de investimento. $\mathrm{O}$ método de custo é utilizado como regra, onde se contabiliza na conta de investimento o valor do custo de aquisição daquela participação societária. Reza o artigo 183, inciso III, da Lei das S.A.:

\footnotetext{
"Art. 183. No balanço, os elementos do ativo serão avaliados segundo os seguintes critérios:

(...)

III - os investimentos em participação no capital social de outras sociedades, ressalvado o disposto nos artigos 248 a 250, pelo custo de aquisição, deduzido de provisão para perdas prováveis na realização do seu valor, quando essa perda estiver comprovada como permanente, e que não será modificado em razão do recebimento, sem custo para a companhia, de ações ou quotas bonificadas".
}

Conclui-se, então, que o método de custo é utilizado quando não estiver determinada a utilização do método de equivalência patrimonial. A regra para utilização do MEP está no artigo 248 da mesma lei:

\footnotetext{
"Art. 248. No balanço patrimonial da companhia, os investimentos em coligadas sobre cuja administração tenha influência significativa, ou de que participe com $20 \%$ (vinte por cento) ou mais do capital votante, em controladas e em outras sociedades que façam parte de um mesmo grupo ou estejam sob controle comum serão avaliados pelo método da equivalência patrimonial, de acordo com as seguintes normas: (Redação dada pela Lei $n^{\circ} 11.638$,de 2007)

(...)

II - o valor do investimento será determinado mediante a aplicação, sobre o valor de patrimônio líquido referido no número anterior, da porcentagem de participação no capital da coligada ou controlada".
}

Como se infere do citado dispositivo, nos casos em que prevê, o MEP é realizado aplicando o percentual da participação societária detida, sobre o valor do patrimônio líquido da sociedade investida. Assim, o aumento no patrimônio líquido da sociedade investida importa em aumento do ativo da investidora, pois sua participação societária passa a ter um valor maior. 
No que diz respeito aos investimentos mantidos em sociedades no exterior, a sociedade investidora sediada no Brasil possui a mesma obrigação de aplicar o método de equivalência patrimonial. No entanto, o valor resultado da equivalência patrimonial é composto não somente pela participação da investidora no resultado (lucro ou prejuízo) do exercício da coligada ou controlada, mas também por variações cambiais do valor do investimento. Vejamos:

\begin{abstract}
"Destaca-se, porém, que o ajuste do investimento ao valor de equivalência patrimonial apresenta uma característica especial, tratada no item 21 do Pronunciamento do Ibracon, como segue:

O ajuste decorrente da comparação do valor final em relação ao valor contábil do investimento representara um ajuste à conta de investimentos, tendo como contrapartida conta de resultado do exercício, à medida que corresponda a ganhos ou perdas efetivos, relativamente (1) à participação da investidora no resultado do exercício da coligada ou controlada e nos acréscimos ou diminuições patrimoniais realizados na coligada ou controlada ou (2) à diferença entre o valor da moeda nacional registrado na conta de investimento e a paridade cambial utilizada". 35
\end{abstract}

Portanto, uma vez que os acréscimos patrimoniais decorrentes da equivalência patrimonial não são compostos apenas de renda decorrente da exploração do capital, essas parcelas merecem tratamento específico pela legislação tributária, como veremos a seguir.

\title{
3.2.1. A tributação no MEP
}

Nos casos em que a sociedade está obrigada a avaliar sua conta de investimento por MEP, ou seja, refletir em seu balanço os resultados da variação patrimonial da sociedade investida, ${ }^{36}$ não há de se falar em tributação do "ganho" decorrente do aumento patrimonial da sociedade investida. A esse respeito, vale dizer que o resultado positivo da equivalência patrimonial não é tributado pelo imposto de renda por força do

\footnotetext{
${ }^{35}$ IUDÍCIBUS, Sérgio de et al.. Manual de Contabilidade das Sociedades por Ações: Aplicável às demais sociedades. $7^{\mathrm{a}}$ ed. São Paulo: Editora Atlas, 2007. p. 182.

${ }^{36}$ Ibid. p. 144.
} 
artigo $23^{37}$ do Decreto-Lei $n^{\circ} 1.598 / 1977$ com redação dada pelo artigo $1^{\circ}$, inciso I do Decreto-Lei n ${ }^{\circ} 1.648 / 1978$.

Quanto à participação societária detida por sociedades brasileiras em sociedades no exterior, a referida sistemática não foi alterada quando da adoção do princípio da universalidade, pois conforme determina o $\S 6^{\circ}$ do artigo 25, da Lei 9.249/95, “os resultados da avaliação dos investimentos no exterior, pelo método da equivalência patrimonial, continuarão a ter o tratamento previsto na legislação vigente (...)".

Entretanto, não se pode deixar de mencionar, que a IN/SRF $n^{\circ}$ 213/2002 - que, como vimos, regulamentou a MP no 2.158-35/2001 extrapolou o que dispõe a legislação do imposto de renda ao criar hipótese de tributação do acréscimo na conta de investimento decorrente do MEP. Seu artigo $7^{\circ}$ assim dispôs:

\begin{abstract}
"Art. $7^{\circ}$ A contrapartida do ajuste do valor do investimento no exterior em filial, sucursal, controlada ou coligada, avaliado pelo método da equivalência patrimonial, conforme estabelece a legislação comercial e fiscal brasileira, deverá ser registrada para apuração do lucro contábil da pessoa jurídica no Brasil

$\S 1^{\circ}$ Os valores relativos ao resultado positivo da equivalência patrimonial, não tributados no transcorrer do ano-calendário, deverão ser considerados no balanço levantado em 31 de dezembro do ano-calendário para fins de determinação do lucro real e da base de cálculo da CSLL".
\end{abstract}

Essa hipótese, mesmo que fosse prevista em lei, causaria dupla tributação no que diz respeito à sistemática imposta pela MP $\mathrm{n}^{\circ} 2.158$ 35/2001, pois se tributaria duas vezes a mesma renda. ${ }^{38}$ A Medida

\footnotetext{
${ }^{37}$ Art. 23: "A contrapartida do ajuste de que trata o artigo 22, por aumento ou redução no valor de patrimônio liquido do investimento, não será computada na determinação do lucro real. (Redação dada pelo Decreto-lei $n^{\circ} 1.648$, de 1978).

Parágrafo único - Não serão computadas na determinação do lucro real as contrapartidas de ajuste do valor do investimento ou da amortização do ágio ou deságio na aquisição, nem os ganhos ou perdas de capital derivados de investimentos em sociedades estrangeiras coligadas ou controladas que não funcionem no País.(Incluído pelo Decreto-lei no 1.648, de 1978)".

${ }^{38}$ COÊLHO, Sasha Calmon Navarro; DERZI, Misabel Abreu Machado. Tributação pelo IRPJ e pela CSLL de Lucros auferidos por empresas controladas ou coligadas no exterior -
} 
Provisória determina que o lucro apurado pela sociedade investida deve ser adicionado, na proporção da participação detida pela sociedade investidora, ao lucro líquido da investidora, para se chegar ao lucro real tributável pelo imposto de renda. Se a hipótese criada pela Instrução Normativa encontrasse previsão legal, o imposto de renda incidiria também sobre a variação positiva na conta de investimento, ou seja, pela segunda vez sobre o mesmo resultado positivo decorrente do investimento no exterior. Cumpre esclarecer, novamente, que o resultado positivo da equivalência patrimonial não contém somente lucro, mas também variação cambial, reservas de lucros acumulados, dentre outras contas que, ao final, somam quantia muito superior ao próprio lucro líquido do período. ${ }^{39}$

Sobre esse mesmo tema, a IN/SRF $n^{\circ}$ 38/96, assim dispôs em seu artigo 11:

\begin{abstract}
"Art. 11. A contrapartida do ajuste de investimento no exterior, avaliado pelo método da equivalência patrimonial, não será computada na determinação do lucro real.

Parágrafo único. Para efeito do disposto neste artigo, os resultados positivos decorrentes do referido ajuste, computados no lucro líquido da empresa no Brasil, poderão ser dele excluídos, enquanto que os resultados negativos deverão ser a ele adicionados, quando da determinação do lucro real".
\end{abstract}

Podemos, portanto, verificar a clara mudança intentada pela Secretaria da Receita Federal ao primeiro editar a IN/SRF no $38 / 96$ com a redação acima transcrita, e seis anos depois editar a IN/SRF $n^{\circ}$ 213/2002 com determinação exatamente oposta. No entanto, a legislação permaneceu inalterada no que diz respeito à tributação do resultado positivo da equivalência patrimonial, devendo este não ser contabilizado na apuração do lucro real da sociedade detentora dos investimentos, independente do que dispõe a IN/SRF n ${ }^{\circ}$ 213/2002.

Inconstitucionalidade do art. 74 da Medida Provisória $\mathrm{n}^{\circ}$ 2.158-35/01. Revista Dialética de Direito Tributário. São Paulo, n. 130, jul. 2006. p. 143.

${ }^{39}$ HIGUCHI, Hiromi et al.. Imposto de Renda das Empresas: Interpretação e prática. $33^{a}$ ed.. São Paulo: IR Publicações Ltda., 2008. p. 121. 


\title{
Capítulo IV - O Conceito de Renda e a Regra-Matriz do IMPOSTO DE RENDA
}

Para analisar a compatibilidade do art. 74 da MP n 2.158-35/01 com o sistema de tributação da renda adotado no Brasil, é indispensável interpretar o fato gerador do IR inscrito no CTN, à luz da Constituição Federal. Assim, a regra-matriz da tributação da renda pode ser divida em critérios material, temporal, espacial, pessoal e quantitativo da norma jurídica que provoca o nascimento da obrigação tributária.

Nesse sentido, veja-se o que diz Paulo de Barros Carvalho:

\begin{abstract}
"No descritor das normas (hipótese, suposto, antecedente) teremos diretrizes para identificação de eventos portadores de expressão econômica. Haverá um critério material (comportamento de alguma pessoa), condicionado no tempo (critério temporal) e no espaço (critério espacial). Já na conseqüência (prescritor), toparemos com um critério pessoal (sujeito ativo e sujeito passivo) e um critério quantitativo (base de cálculo e alíquota). A conjunção desses dados indicativos nos oferece a possibilidade de exibir, na plenitude, o núcleo lógico-estrutural da norma-padrão, preenchido com os requisitos significativos necessários e suficientes para o impacto jurídico da exação".
\end{abstract}

Então, temos que no caso da tributação da renda das pessoas jurídicas domiciliadas no Brasil, os critérios espacial, pessoal e quantitativo não encontram maiores problemas no que diz respeito aos lucros auferidos no exterior pelas sociedades investidas.

Em linhas gerais, cumpre esclarecer que introduzido o princípio da universalidade, e nos termos do artigo 74, da MP no 2.158-35/01 então vigente, os sujeitos ativo e passivo da relação tributária - critério pessoal permanecem inalterados. A questão de que trata o artigo 74 da MP, em questão, é justamente o momento que se dá a disponibilidade da renda para fins de tributação. É, portanto, imprescindível o estudo dos critérios

\footnotetext{
${ }^{40}$ CARVALHO, Paulo de Barros. Fundamentos Jurídicos da Incidência Tributária. São Paulo: USP, 1996. p. 79.
} 
temporal e material, consubstanciado na regra-matriz do imposto de renda, com respeito aos quais a Medida Provisória pretendeu alterar por via do permissivo artigo $43, \S 2^{\circ}$ do CTN acrescentado pela Lei Complementar $n^{\circ}$ $104 / 2001$.

\subsection{Os critérios material e temporal da regra-matriz do imposto de renda}

Por critério material, entende-se a ação da qual o resultado é a hipótese prescrita em lei, que neste caso, gera a obrigação ao pagamento do imposto. Só há renda a ser tributada se renda for auferida, nesse sentido, se houver acréscimo patrimonial. A materialidade está justamente na ação de "auferir renda". Entretanto, não basta que seja praticada a conduta que enseja o acréscimo patrimonial; é preciso que este acréscimo esteja disponível, entendido assim o critério temporal.

Para facilitar, vejamos abaixo a transcrição completa do art. 43 do CTN:

\footnotetext{
"Art. 43. O imposto de competência da União, sobre a renda e proventos de qualquer natureza tem como fato gerador a aquisição da disponibilidade econômica ou jurídica:

I - de renda, assim entendido o produto do capital, do trabalho ou da combinação de ambos;

II - de proventos de qualquer natureza, assim entendidos os acréscimos patrimoniais não compreendidos no inciso anterior.

$\S 1^{\circ}$ A incidência do imposto independe da denominação da receita ou do rendimento, da localização, condição jurídica ou nacionalidade da fonte, da origem e da forma de percepção.

$\S 2^{\circ} \mathrm{Na}$ hipótese de receita ou de rendimento oriundos do exterior, a lei estabelecerá as condições e o momento em que se dará sua disponibilidade, para fins de incidência do imposto referido neste artigo" (grifou-se).
}

${ }^{41}$ OKUMA, Alessandra. Da Tributação das Empresas Coligadas e Controladas. In: TÔRRES, Heleno Taveira (Coord.). Direito Tributário Internacional aplicado. v. 4. São Paulo: Quartier Latin, 2004. p. 518. 
$\mathrm{O}$ critério temporal fica evidente no que dispõe o caput e $\S 2^{\circ}$ do artigo 43, através do emprego, respectivamente, das expressões "aquisição da disponibilidade" e "momento em que se dará sua disponibilidade". Ora, só haverá renda a ser tributada depois desta estar disponível. Verifica-se, então, que o critério temporal está estritamente relacionado ao critério material, pois o "momento da disponibilidade" será definido por lei; entretanto, deverá respeitar o critério material do dispositivo ora comentado. $^{42}$

\subsubsection{O conceito de renda como objeto do critério material}

Muito se debate sobre a existência de um conceito constitucional de renda, a que o legislador estaria submetido. Num primeiro momento, a legislação infraconstitucional trata da matéria com certa objetividade. $\mathrm{O}$ CTN definiu renda como o "produto do capital, do trabalho ou da combinação de ambos", e proventos de qualquer natureza como "acréscimos patrimoniais não compreendidos no conceito de renda" ${ }^{43}$ Por lógico, verifica-se que acréscimo patrimonial é noção mais ampla, ou seja, é gênero do qual renda é espécie, assim entendida ela própria como uma forma de "acréscimo". 44

O legislador ordinário está afastado, portanto, do papel de definir o conceito de renda, tarefa essa cumprida pelo CTN, tendo em vista que a própria Constituição Federal determinou que:

"Art. 146. Cabe à lei complementar:

\footnotetext{
42 OKUMA, Alessandra. Da Tributação das Empresas Coligadas e Controladas. In: TÔRRES, Heleno Taveira (Coord.). Direito Tributário Internacional aplicado. v. 4. São Paulo: Quartier Latin, 2004. p. 518.

${ }^{43}$ Artigo 43, incisos I e II, do CTN.

${ }^{44}$ Hugo de Brito entende a renda como acréscimo patrimonial ao dizer que: "como a renda envolve necessariamente a idéia de acréscimo patrimonial, ainda que esse acréscimo nem sempre seja efetivo, tem-se de admitir que não existe renda se não houver pelo menos a possibilidade de efetivar-se um acréscimo patrimonial" (MACHADO, Hugo de Brito. Comentários ao Código Tributário Nacional: Artigos $1^{\circ}$ a 95. v. 1. São Paulo: Editora Atlas, 2003. p. 431).
} 
(...)

III - estabelecer normas gerais em matéria de legislação tributária, especialmente sobre:

a) definição de tributos e de suas espécies, bem como, em relação aos impostos discriminados nesta Constituição, a dos respectivos fatos geradores, bases de cálculo e contribuintes".

Assim, a definição contida no CTN é até certo ponto satisfatória e objetiva, o que permite à doutrina, com clareza, concluir que a renda tributável é o acréscimo patrimonial. ${ }^{45} \mathrm{Na}$ prática, significa que no caso da pessoa jurídica, não pode o IR recair sobre o próprio patrimônio (riqueza velha) da empresa, mas tão somente sobre o valor a ele agregado, ou seja, sobre o lucro (riqueza nova). Portanto, o sujeito passivo, que não experimenta saldo positivo entre riqueza velha e riqueza nova, num dado lapso temporal, não tem para si nascida a obrigação tributária. ${ }^{46}$

\section{Esse é também o entendimento de Misabel Derzi:}

"o lucro só é tributável se há uma mudança patrimonial - acréscimo de valor efetiva e concreta, que se tornou dinheiro ou em valor equivalente; enfim, quando está realizado". 47

No entanto, o tema recebe diversos tratamentos pela melhor doutrina, pois a CF88, não deixou liberdade total ao legislador complementar, para este definir o que é renda, e, tampouco, a definiu expressamente. Cabe, então, o questionamento sobre a possibilidade da elaboração de um conceito constitucional para a renda. A simples disposição de que "compete à União

\footnotetext{
${ }^{45}$ Sobre conceito de renda e acréscimo patrimonial, Roberto Quiroga acrescenta que: "A palavra 'renda' e a expressão 'proventos de qualquer natureza' significam acréscimos de elementos patrimoniais de uma determinada pessoa, isto é, o incremento de direitos reais e pessoais ao patrimônio pessoal. Em outro dizer, o aspecto mateiral da hipótese de incidência do imposto inserto no artigo 153, inciso III, da Carta Republicana de 1988, representa a mutação patrimonial que se constitui num acréscimo de seus elementos. Esses acréscimos, em síntese, representam aqueles valores recebidos provenientes do trabalho, do capital, da aposentadoria e de quaisquer outras fontes geradoras de majoração patrimonial. A pedra de toque na conceituação adotada é que esses valores recebidos representam riqueza nova" (MOSQUERA, Roberto Quiroga. Renda e proventos de qualquer natureza: o imposto e o conceito constitucional. São Paulo: Dialética, 1996. p. 106-107.).

${ }^{46}$ CARRAZZA, Roque Antonio. Imposto sobre a Renda: perfil constitucional e temas específicos. São Paulo: Malheiros editores, 2005. p. 46/47.

${ }^{47}$ BALEEIRO, Aliomar; DERZI, Misabel Abreu Machado. Direito Tributário Brasileiro. $11^{\mathrm{a}} \mathrm{ed}$. São Paulo: Editora Forense, 2003. p. 304.
} 
instituir impostos sobre renda e proventos de qualquer natureza", ${ }^{48}$ delimita o espaço de atuação da norma complementar, visto que se coubesse a ela definir livremente o conceito de renda, estaria a descaracterizar, por exemplo, o propósito da repartição de competências entre União, Estados e Municípios, para instituir impostos. Significa dizer que a lei poderia definir livremente o que é renda, podendo inclusive, atribuir à renda conceitos tão amplos que englobariam noções concernentes a impostos de competência dos Estados e Municípios. Hugo de Brito assevera que:

\begin{abstract}
"Entender que o legislador pode alterar o conceito de renda é o mesmo que entender que o legislador pode alterar a norma da Constituição, na qual o mesmo está colocado. Se o legislador pudesse alterar o conceito de renda, sem violar a Constituição, teríamos que fazer uma outra leitura de ser art. 153, inciso I [sic]. Teríamos de ler esse dispositivo da Constituição assim: Compete à União instituir impostos sobre: 'III - tudo o que o legislador entender cabível.' E isso evidentemente não se pode admitir porque seria destruir totalmente a supremacia constitucional e com ela a partilha das rendas tributárias e a própria federação". ${ }^{4}$
\end{abstract}

É, portanto, imprescindível que a Constituição Federal veicule conceitos de forma intrínseca, pois se não o fizesse, seria um texto vazio de significado, incapaz de produzir efeitos na construção de um ordenamento jurídico. Assim explica Luís César Souza de Queiroz:

\begin{abstract}
"É fundamental reiterar que a Constituição da República se apresenta em forma de texto, que, por sua vez, é composto por palavras. As palavras são signos simbólicos que exprimem um significado. As palavras são a expressão verbal de conceitos. Portanto, para que seja possível considerar que a Constituição da República apresenta um texto com algum sentido, é necessário compreender que as palavras que o integram representam conceitos, os quais apresentam limites máximos. Em outros termos, a consideração de que a Constituição da República veicula conceitos com limites máximos é pressuposto necessário para a existência de um sistema com sentido; um sistema que não seja um nada jurídico" (grifos no original). ${ }^{50}$
\end{abstract}

Em sua obra, Luís César conduz os passos para a construção do conceito de renda estabelecido na Constituição. Basicamente, o método

\footnotetext{
${ }^{48}$ Artigo 153, inciso III, da CF/88.

${ }^{49}$ MACHADO, Hugo de Brito. Comentários ao Código Tributário Nacional:Artigos $1^{\circ}$ a 95. v. 1. São Paulo: Editora Atlas, 2003. p. 427.

${ }^{50}$ QUEIROZ, Luís César Souza de. Imposto sobre a Renda: Requisitos para uma tributação constitucional. Rio de Janeiro: Editora Forense, 2003. p. 218.
} 
compreende (i) investigar o contexto em que a expressão "renda e proventos de qualquer natureza" se encontra inserida na Constituição; (ii) buscar os limites máximos do conceito da mencionada expressão em uma perspectiva pré-constitucional, ou seja, num plano meramente teórico no discurso da comunidade; e, (iii) combinar a mais ampla definição teórica do conceito com os enunciados prescritivos originais da Constituição Federal de 1988, para ao final obter um conceito amplo, resultado da reunião de todos os valores constitucionalmente positivados. ${ }^{51}$ Por conseguinte, o resultado de seu estudo pelos métodos expostos é o seguinte conceito de "renda e proventos de qualquer natureza":

\begin{abstract}
"Renda e proventos de qualquer natureza (ou renda em sentido amplo ou simplesmente Renda) é conceito que está contido em normas constitucionais relativas ao imposto sobre a renda e proventos de qualquer natureza e que designa o acréscimo de valor do patrimônio, apurado, em certo período de tempo, a partir da combinação de todos os fatos que contribuem para o acréscimo de valor do patrimônio (fatos-acréscimos) com certos fatos que, estando relacionados ao atendimento das necessidades vitais básicas ou à preservação da existência, com dignidade, tanto da própria pessoa quanto de sua família, contribuem para o decréscimo de valor do patrimônio (fatosdecréscimos)" ${ }^{52}$ (grifos no original).
\end{abstract}

Portanto, podemos concluir que a regra-matriz do imposto de renda encontra previsão constitucional, atuando como limitadora ao legislador infraconstitucional no seu papel de definir tributos e suas espécies.

\title{
4.1.2. O conceito de disponibilidade como objeto do critério temporal
}

Em continuidade ao raciocínio traçado no item anterior, o aspecto temporal da tributação da renda é elemento complementar para a definição do fato gerador, sendo de extrema relevância para o tema exposto no presente trabalho. Como anteriormente mencionado, o caput do art. 43 do

\footnotetext{
${ }^{51}$ QUEIROZ, Luís César Souza de. Imposto sobre a Renda: Requisitos para uma tributação constitucional. Rio de Janeiro: Editora Forense, 2003. p. 220.

${ }^{52}$ QUEIROZ, Luís César Souza de. Imposto sobre a Renda: Requisitos para uma tributação constitucional. Rio de Janeiro: Editora Forense, 2003. p. 239.
} 
CTN define como fato gerador do imposto a "aquisição da disponibilidade" da renda. Assim, nos interessa analisar quando se dá a mencionada "disponibilidade", pois é no instante em que ela se dá que acontece o fato descrito - auferir renda -, acarretando o nascimento do vínculo jurídico entre sujeito passivo e sujeito ativo da obrigação tributária.

Adquirir disponibilidade significa que a renda auferida, ou seja, que o objeto auferido deixa de fazer parte de um conjunto de elementos, passando a fazer parte de outro. Com efeito, pressupõe a transferência do objeto de uma pessoa para o patrimônio da pessoa que o auferiu, ou seja, dá-se a incorporação do acréscimo patrimonial ao patrimônio de quem o auferiu. $^{53}$

\title{
Assim define José Luiz Bulhões de Pedreira:
}

\begin{abstract}
"Adquirir a disponibilidade de renda é obter, alcançar ou passar a ter o poder de dispor da moeda (ou do valor em moeda do objeto de direitos patrimoniais).

Poder de dispor é poder de usar livremente, dar aplicação ou depender. Dispor da renda é ter o poder de usar a moeda (ou o valor em moeda de direitos patrimoniais).
\end{abstract}

A propriedade é o instrumento do sistema jurídico para assegurar o poder de dispor de moeda, bens econômicos ou recursos. O direito de dispor é um dos elementos da propriedade e assegura ao proprietário o poder jurídico de dar à coisa, objeto do domínio, o destino que lhe aprouver - usando-a, consumindo-a ou transferindo-a a terceiros. O dinheiro assegura o poder de dispor da moeda. Outros direitos reais asseguram o poder de dispor de bens econômicos. Os direitos de crédito não asseguram poder de dispor da renda, mas de exigir do devedor a prática do ato que cria a disponibilidade da renda.

A aquisição do poder de dispor pressupõe, por conseguinte, a aquisição do direito à renda, e por isso o CTN define como contribuinte o titular da disponibilidade da renda (v. obs. 3 ao $\left.n^{\circ} 3\right)$,. 54

\footnotetext{
53 OKUMA, Alessandra. Da Tributação das Empresas Coligadas e Controladas. In: TÔRRES, Heleno Taveira (Coord.). Direito Tributário Internacional aplicado. v. 4. São Paulo: Quartier Latin, 2004. p. 518/519.

${ }^{54}$ PEDREIRA, José Luiz Bulhões. Imposto sobre a Renda: Pessoas Jurídicas. v. 1. Rio de Janeiro: Adcoas/Justec, 1979. p. 196.
} 
No caso dos lucros auferidos no exterior, a incorporação do acréscimo patrimonial ao patrimônio do contribuinte sediado no Brasil se verifica quando este passa a ter poder de dispor desses lucros, o que, nas coligadas a controladas, por exemplo, só se dá após a deliberação por distribuí-los. A seguir, o esclarecimento sobre o significado de disponibilidade econômica e jurídica facilita o entendimento do critério temporal.

\subsubsection{A disponibilidade econômica e jurídica}

$\mathrm{O}$ art. 43, caput, do $\mathrm{CTN}$, define o fato gerador do imposto de renda como "a aquisição da disponibilidade econômica ou jurídica". Em princípio, a diferença entre disponibilidade econômica e jurídica está no fato de que na primeira, temos o efetivo recebimento do valor, no que a renda já integra o patrimônio do contribuinte, e na segunda, o que se tem é o direito efetivo ao valor, ou seja, ele é creditado ao contribuinte. É o que esclarece Hugo de Brito:

\footnotetext{
"A disponibilidade econômica decorre do recebimento do valor que se vem a acrescentar o patrimônio do contribuinte. Já a disponibilidade jurídica decorre do simples crédito desse valor, do qual o contribuinte passa a juridicamente dispor, embora este não lhe esteja ainda nas mãos". ${ }^{55}$
}

Temos que a disponibilidade jurídica em tela é aquela da qual o contribuinte não encontra qualquer obstáculo ou resistência para incorporar o valor ao seu patrimônio ou lançar mão dele. A Lei nº 9.532/97 especificou a distinção entre as formas de disponibilidade ao tratar sobre o tema da tributação de lucros auferidos no exterior. Vejamos:

\footnotetext{
"Art. $1^{\circ}$ : Os lucros auferidos no exterior, por intermédio de filiais, sucursais, controladas ou coligadas serão adicionados ao lucro líquido, para determinação do lucro real correspondente ao balanço levantado no dia 31 de dezembro do ano-
}

\footnotetext{
${ }^{55}$ MACHADO, Hugo de Brito. Curso de Direito Tributário. $29^{\mathrm{a}}$ ed.. São Paulo: Malheiros, 2008. p. 315.
} 
calendário em que tiverem sido disponibilizados para a pessoa jurídica domiciliada no Brasil. (Vide Medida Provisória $\mathrm{n}^{\circ}$ 2158-35, de 2001)

$\S 1^{\circ}$ Para efeito do disposto neste artigo, os lucros serão considerados disponibilizados para a empresa no Brasil:

a) no caso de filial ou sucursal, na data do balanço no qual tiverem sido apurados; b) no caso de controlada ou coligada, na data do pagamento ou do crédito em conta representativa de obrigação da empresa no exterior" (não grifado no original).

Dessa forma, verificamos e existência de distinção entre o pagamento (disponibilidade econômica) e o crédito (disponibilidade jurídica). Na sequiência, o parágrafo $2^{\circ}$ do citado artigo define que considera creditado o lucro, "quando ocorrer a transferência do registro de seu valor para qualquer conta representativa de passivo exigível da controlada ou coligada domiciliada no exterior"; e pago, quando ocorrer: (i) "o crédito do valor em conta bancária, em favor da controladora ou coligada no Brasil"; (ii) "a entrega, a qualquer título, a representante da beneficiária"; (iii) "a remessa, em favor da beneficiária, para o Brasil ou para qualquer outra praça"; e, (iv) "o emprego do valor, em favor da beneficiária, em qualquer praça, inclusive no aumento de capital da controlada ou coligada, domiciliada no exterior".

Portanto, independente do meio em que se dá a disponibilidade da renda, conclui-se que para a ocorrência do fato gerador do imposto de renda, o contribuinte deve ter a renda na sua esfera de disposição, sem que nada obste a sua decisão de lançar mão de utilizá-la como bem entender. 


\title{
CAPÍtulo V - A Ficção JuRídicA do ART. 74 dA MP 2.158- $35 / 2001$
}

Como já mencionado, o artigo 74 da MP 2.158-35/2001 retomou, para as controladas e coligadas, a sistemática antes criada pelo artigo 25 da Lei $n^{\circ}$ 9.249/95. Assim, restou igualado o momento da tributação dos lucros auferidos por filiais, sucursais, coligadas e controladas sediadas no exterior, antes diferenciado pela Lei ${ }^{\circ}$ 9.532/97.

Dizer que "os lucros auferidos por controlada ou coligada no exterior serão considerados disponibilizados para a controladora ou coligada no Brasil na data do balanço no qual tiverem sido apurados", 56 é criar uma ficção jurídica ${ }^{57} \mathrm{O}$ emprego da palavra "considera-se", por si só, denota a dissociação do comando legal com relação ao mundo fático, ficando a norma absoluta no papel de prescrever e produzir efeitos no mundo jurídico. Assim, pode-se entender que independente do que ocorra no mundo fático, a norma jurídica produzirá os efeitos pretendidos decorrentes da presunção de existência de determinado evento por ela tipificado.

A respeito das ficções jurídicas no direito tributário, José Artur Lima Gonçalves, afirma:

\begin{abstract}
"Todas - e não menos que todas - as normas jurídicas que pretendam, por meio de ficção, imputar os efeitos de fato imponível a evento fenomênico que não se caracterize como tal, ou manipular o conteúdo patrimonial da obrigação tributária, ou alcançar particular não incluído na categoria de contribuinte (entendido este como o destinatário constitucional da carga tributaria), deverão, simplesmente, ser descritas como normas válidas, alheias ao sistema constitucional, incompatíveis com o subsistema constitucional tributário". ${ }^{58}$
\end{abstract}

\footnotetext{
${ }^{56}$ Caput do artigo 74, da MP n $2.158-35 / 2001$.

57 ÁVILA, Humberto. O Imposto de Renda, a Contribuição Social sobre o Lucro e os Lucros Auferidos no Exterior. In: ROCHA, Valdir de Oliveira (Coord.). Grandes questões atuais do Direito Tributário. v. 7. São Paulo: Dialética, 2003. p. 226.

${ }^{58}$ GONÇALVES, José Artur Lima. Imposto sobre a renda: Pressupostos constitucionais. São Paulo: Editora Malheiros, 1997. p. 158.
} 
Nesse caso, a ficção da disponibilidade da renda atinge tão somente o critério temporal da regra-matriz do imposto de renda das pessoas jurídicas. O aspecto temporal é verificado, como vimos, pelo momento em que se dá a disponibilidade da renda, ou seja, momento em que a renda ingressa no patrimônio de quem a auferiu. É de suma importância, pois, considerar que, se a sociedade investidora sediada no Brasil tiver de suportar a carga do imposto de renda incidente sobre os lucros auferidos no exterior por suas investidas, antes da efetiva transferência de tais recursos a seu favor, se verificará um decréscimo patrimonial do sujeito passivo, o que configuraria o confisco ${ }^{59}$ vedado pelo art. 150 , inciso IV, da CF/88.

Independente do tratamento dado pela norma, no mundo fático, o momento efetivo da disponibilidade para as empresas ocorre quando os lucros forem distribuídos pelo consenso dos sócios ou acionistas, e não na data do levantamento do balanço. ${ }^{60}$ Cabe mencionar que o levantamento do balanço é necessário para verificar se no período de apuração houve prejuízo ou lucro, e na existência do segundo, proceder à deliberação sobre o montante a ser distribuído ou não.

A respeito desse entendimento, a doutrina parece ser uníssona. Misabel Derzi aduz que:

"O conceito de renda decorre da Constituição. É validamente complementado pelo art. 43 do Código Tributário Nacional, que se presta à elucidação dos conflitos de competência tributária. Mas o legislador ordinário não pode criar ficções jurídicas de renda-lucro. Se pudesse fazê-lo, estaria falseada a

\footnotetext{
59 "Estamos também convencidos de que o princípio da não-confiscatoriedade... deriva do principio da capacidade contributiva. Realmente, as leis que criam impostos, a levarem em conta a capacidade econômica dos contribuintes não podem compeli-los a colaborar com os gastos públicos além de suas possibilidades. Estamos vendo que é confiscatório o imposto que, por assim dizer, esgota a riqueza tributável das pessoas, insto é, que não leva em conta suas capacidades contributivas" (CARRAZZA, Roque Antônio. Curso de Direito Constitucional Tributário. 9ª ed.. São Paulo: Editora Malheiros, 1997. p. 70.).

${ }^{60}$ MATTOS, Aroldo Gomes de. Lucros, prejuízos e perdas, apurados no exterior. Tratamento tributário no Brasil. In: ROCHA, Valdir de Oliveira (Coord.). Grandes questões atuais do direito tributário. v. 6. São Paulo: Dialética, 2002. p. 23.
} 
discriminação constitucional de competência tributaria, porque ele converteria o que é renda em patrimônio e vice-versa". ${ }^{61}$

Ricardo Mariz de Oliveira acrescenta argumentos de invalidade do comando contido na MP:

\begin{abstract}
"Destarte, a regra inserida na Medida Provisória $\mathrm{n}^{\circ}$ 2.158-34 é francamente inválida, por instituir uma ficção de renda adquirida onde renda não existe e onde, por conseqüência, muito menos pode existir, ainda que minimamente, disponibilidade de renda.

A regra dessa medida provisória não apenas entra em choque com a totalidade do ordenamento jurídico, que a repele implacavelmente, como também não se subsume à própria previsão do $\$ 2^{\circ}$ do art. 43 do $\mathrm{CTN}$, que se limita a dar ao legislador comum a possibilidade de definir como e quando ocorre a aquisição da disponibilidade de rendas e proventos obtidos no exterior, desde que, a toda evidência, respeite os limites da realidade factual e jurídica em que as normas atuam e também observe os limites do poder de tributar". ${ }^{62}$
\end{abstract}

Num amplo estudo sobre o tema, Gilberto de Ulhôa Canto, ${ }^{63}$ em situação análoga à presente, na qual pretendia-se, por presunção, a tributação da pessoa física por via reflexa da pessoa jurídica, fundamentou seu entendimento da seguinte forma:

"5.3. muito embora se possa admitir como lógico que os resultados líquidos auferidos pelas pessoa jurídicas de fins econômicos se destinam, em última instância, àqueles que detêm o seu capital social, é preciso não esquecer a nítida separação que existe entre a empresa e os seus sócios. Na verdade, a grande importância da ficção legal da personalidade jurídica reside em tornar possível a separação de parte do patrimônio da pessoa física, junto com as partes dos patrimônios de outras, formar o patrimônio social afetado, único a responder pelas obrigações desta última. Foi a partir dessa realidade legal que se construiu a teoria da tributação das pessoas jurídicas como entes distintos dos seus participantes.

5.4. Portanto, quando se diz que no mero fato de ser estabelecido que a pessoa jurídica auferiu lucro se pode inferir desde logo que seus sócios adquiriram disponibilidade, mesmo jurídica, sobre esses lucros, está-se a desconsiderar que juridicamente os lucros e as reservas pertencem à sociedade até que sobrevenha decisão, pelo órgão e na forma legais, no sentido de serem eles distribuídos aos

\footnotetext{
${ }^{61}$ DERZI, Misabel Abreu Machado. Correção Monetária e Demonstrações Financeiras - Conceito de Renda - Imposto sobre patrimônio - lucros fictícios - direito adquirido a deduções e correções - Lei 8.200/91. Revista de Direito Tributário. São Paulo, n. 59. p. 145.

${ }^{62}$ OLIVEIRA, Ricardo Mariz de. O Conceito de Renda - Inovação do art. 43 do CTN pela Lei Complementar no 104 (a Questão da Disponibilidade sobre Lucros de Coligadas e Controladas no Exterior). Revista Dialética de Direito Tributário. São Paulo, n. 73, out. 2001. p. 114-115.

${ }^{63}$ CANTO, Gilberto de Ulhôa. Presunções no Direito Tributário. In: MARTINS, Ives Gandra da Silva (Coord.). Cadernos de pesquisas tributárias: Presunções no Direito Tributário. v. 9. São Paulo: Resenha Tributária, 1991. p. 27-28.
} 
seus sócios ou acionistas, já que temos, em verdade, contribuintes distintos: a pessoa jurídica quanto ao lucro que realiza, e seus sócios quanto às parcelas de tais lucros sociais que lhe são distribuídas.

5.5. O caso é, assim, justamente o mesmo de todas as situações específicas antes examinadas: não é possível presumir a ocorrência do fato gerador do imposto de renda para os sócios a partir da circunstância de se ter materializado o fato gerador da pessoa jurídica com referência ao lucro que esta auferiu. Também não se cogita de ficção, pois nenhuma norma de lei afirma a ocorrência do fato gerador para os sócios nas circunstâncias analisadas: de resto, mesmo que houvesse lei estabelecendo tal ficção ela não poderia prevalecer, por ser contrária ao conceito de fato gerador do imposto de renda constante no art. 43 do CTN".

É de se verificar que a doutrina em peso condena o uso da ficção jurídica tributária: em primeiro lugar, porque ela se destaca da realidade fática e cria eventos existentes apenas no mundo jurídico, e em segundo lugar, porque no caso do IRPJ sobre lucros auferidos no exterior por coligadas e controladas, há a total desconsideração da personalidade jurídica das sociedades investidas, como se elas não gozassem de perfeita autonomia perante a sociedade investidora.

No entanto, os tribunais não têm entendido dessa forma. Antes de tudo, o entendimento tem sido no sentido de que a Lei Complementar $\mathrm{n}^{\mathrm{o}}$ 104/2001, ao inserir o $\$ 2^{\circ}$ no art. 43 do CTN, delegou perfeitamente ao legislador ordinário o papel de definir o exato momento em que ocorreria a disponibilidade da renda no caso de lucros auferidos no exterior. Em conjunto com o permissivo da legislação complementar, aduz-se de forma obscura a idéia de que, por força da equivalência patrimonial, a apuração de lucro na sociedade investida estrangeira tem reflexos imediatos no patrimônio da sociedade investidora brasileira. Vejamos a ementa do acórdão proferido pelo Tribunal Regional Federal da $4^{\mathrm{a}}$ Região, nos autos da Apelação em Mandado de Segurança no 2002.70.00.069334-0: ${ }^{64}$

\footnotetext{
“TRIBUTÁRIO. MANDADO DE SEGURANÇA. IMPOSTO DE RENDA PESSOA JURÍDICA. CONTRIBUÇÃO SOCIAL SOBRE O LUCRO LÍQUIDO. LUCROS AUFERIDOS POR EMPRESAS CONTROLADAS NO EXTERIOR. LEI No 9.249/95. LEI No 9.532/97. MP N N $^{\circ} .158-35 / 2001$.
}

\footnotetext{
${ }^{64}$ TRF $4{ }^{a}$ Região, Apelação em Mandado de Segurança n. 2002.70.00.069334-0, Rel. Des. Federal Dirceu de Almeida Soares, Porto Alegre, 06 dez. 2005. DJU 15 fev. 2006.
} 
1. Nos termos do disposto no art. 153, III, da CF/88, e no art. 43 do CTN, o âmbito material de incidência do imposto de renda é aquisição da disponibilidade econômica ou jurídica de renda, assim entendido o produto do capital, do trabalho ou da combinação de ambos; e de proventos de qualquer natureza, assim entendidos os acréscimos patrimoniais não compreendidos no conceito de renda.

2. A Lei Complementar $n^{\circ} 104 / 2001$ incluiu o $\S 2^{\circ}$ no art. 43 do CTN, cuja disposição remete à lei ordinária o poder de disciplinar as condições e o momento que se considerará a disponibilidade da receita ou de rendimentos oriundos do exterior, para fins de incidência tributária.

3. $\mathrm{O}$ art. 25 da Lei $\mathrm{n}^{\circ} 9.249 / 95$, determinava, por sua vez, que os lucros auferidos no exterior deveriam ser computados no balanço da controladora, levantado em 31 de dezembro de cada ano.

4. $\mathrm{O}$ art. $1^{\circ}$ da Lei $\mathrm{n}^{\mathrm{o}}$ 9.532/97, no que concerne aos lucros auferidos por empresas controladas no exterior, especificava o momento em que os lucros da controlada deveriam ser adicionadas ao lucro líquido da controladora brasileira, definindo que os lucros seriam considerados disponibilizados para a empresa no Brasil, na ata do pagamento ou do crédito em conta representativa de obrigação da empresa no exterior.

5. A Medida Provisória $n^{\circ} 2.158-35 / 01$ alterou o momento em que se consideraria a "disponibilização", consignando que esta ocorre na data do balanço no qual os lucros tenham sido apurados.

6. De acordo com o método da equivalência patrimonial, aplicável na avaliação dos investimentos em empresas controladas, nos termos da Lei $\mathbf{n}^{\mathbf{0}}$ 6.404/76, a apuração do lucro na sociedade controlada tem reflexos imediatos no patrimônio da controladora, pois o valor do investimento é determinado mediante a aplicação, sobre o valor de patrimônio líquido da controlada, da porcentagem de participação no capital da coligada ou controlada.

7. A valorização do investimento da empresa controladora configura acréscimo patrimonial, sujeito à incidência tributária. Com a apuração dos lucros na sociedade controlada, a pessoa jurídica controladora adquire imediatamente a disponibilidade econômica da renda que se incorpora em seu patrimônio, acrescentando-lhe valor, bem como a disponibilidade jurídica da renda, pois terá título jurídico para pleitear e defender o direito

relativo a essa renda.

8. A MP n. 2.158-35/2001, ao adotar a data do balanço em que os lucros tenham sido apurados na controlada, independentemente do seu efetivo pagamento ou crédito, não maculou a regra-matriz da hipótese de incidência do imposto de renda contida no caput do art. 43 do $\mathrm{CTN}$, pois, pré-existindo o acréscimo patrimonial, a lei estava autorizada a apontar o momento em que se considerariam disponibilizados os lucros apurados pela empresa controlada" (grifou-se).

Na hipótese, não satisfeita, a Apelante interpôs Recurso Especial ao STJ, cujo acórdão proferido nos autos do RESP nº 907.404/PR restou assim ementado: ${ }^{65}$

"TRIBUTÁRIO - IMPOSTO DE RENDA PESSOA JURÍDICA CONTRIBUIÇÃO SOCIAL SOBRE O LUCRO - LUCROS AUFERIDOS POR EMPRESAS CONTROLADAS SITUADAS NO EXTERIOR -

\footnotetext{
${ }^{65}$ STJ, RESP n. 907.404/PR, Rel. Min. Humberto Martins, Brasília, 23 out. 2007. DJU 13 nov. 2007.
} 
DISPONIBILIDADE JURÍDICA DA RENDA - ART. 74 DA MP. N. 2.15835/2001 - HIPÓTESE DE INCIDÊNCIA CONTIDA NO CAPUT DO ART. 43 DO CTN - ENTENDIMENTO QUE SE COADUNA COM O ATUAL POSICIONAMENTO DO STF.

1. A análise da aplicação de uma lei federal não é incompatível com o exame de questões constitucionais subjacentes ou adjacentes.

2. Para que haja a disponibilidade econômica, basta que o patrimônio resulte economicamente acrescido por um direito, ou por um elemento material, identificável como renda ou como proventos de qualquer natureza. Não importa que o direito ainda não seja exigível (um título de crédito ainda não vencido), ou que o crédito seja de difícil e duvidosa liquidação (contas a receber). O que importa é que possam ser economicamente avaliados e, efetivamente, acresçam ao patrimônio. (Zuudi Sakakihara in 'Código Tributário Nacional Comentado', coordenador Vladimir Passos de Freitas, Ed. RT, p. 133).

3. A Medida Provisória n. 2.158-35/2001, ao adotar a data do balanço em que os lucros tenham sido apurados na empresa controlada, independentemente do seu efetivo pagamento ou crédito, não maculou a regra-matriz da hipótese de incidência do imposto de renda contida no caput do art. 43 do CTN, pois, pré-existindo o acréscimo patrimonial, a lei estava autorizada a apontar o momento em que se considerariam disponibilizados os lucros apurados pela empresa controlada.

4. O entendimento firmado coaduna-se com a tese que prevalece no julgamento de mérito da ADI n. 2.588, no qual a eminente relatora Ministra Ellen Gracie proferiu voto no sentido de julgar procedente, em parte, o pedido formulado na inicial, para declarar a inconstitucionalidade apenas da expressão "ou coligada", duplamente contida no caput do referido art. 74, por ofensa ao disposto no art. 146, III, "a", da Constituição Federal, que reserva à lei complementar a definição de fato gerador.

5. A hipótese dos autos, todavia, cuida de empresas controladas localizadas no exterior, situação em que há posição de controle das empresas situadas no Brasil sobre aquelas" (grifou-se).

Fica claro o posicionamento do Superior Tribunal de Justiça, que no exercício da sua competência infraconstitucional, manifestou-se pela validade do dispositivo contido no art. 74 da MP em tela. O acórdão ora mencionado não adentra questões mais profundas porquanto a matéria envolve, com maior predominância, questões constitucionais.

No entanto, é de se afirmar, na análise estrita da legalidade, que a determinação do art. 74 da MP 2.158-35/2001, está de acordo com o que preceitua o legislador complementar quando promoveu a inserção do $\S 2^{\circ}$ ao artigo 43 do CTN. 


\section{CAPÍTULO VI - A ADI 2.588 E O ENTENDIMENTO dO STF}

Como era de se esperar, após as sucessivas tentativas de se construir um sistema legal coerente, capaz de adotar o princípio da universalidade da tributação da renda, poucos meses depois da última reedição da Medida Provisória 2.158, foi proposta Ação Direta de Inconstitucionalidade no Supremo Tribunal Federal, autuada sob o número 2.588. A ação objetiva a declaração da inconstitucionalidade do (i) artigo 74, caput e parágrafo único da Medida Provisória ${ }^{\circ}$ 2.158-35/2001; e, (ii) $\S 2^{\circ}$ do artigo 43 do CTN, acrescentado pela Lei Complementar $n^{\circ}$ 104/2001, para, ao final, ter afirmada a interpretação de que a lei só pode considerar ocorrido o fato gerador, nas hipóteses de receita ou rendimento auferidos no exterior, após a aquisição de disponibilidade econômica ou jurídica de renda ou proventos de qualquer natureza.

A ADI foi proposta pela Confederação Nacional da Indústria ("CNI"), e ataca requisitos formais e materiais de validade da MP 2.15835/2001. No que tange ao IRPJ, alega (i) violação ao artigo $62^{66}$ da Constituição, diante da total falta de urgência para regular a matéria; (ii) violação ao artigo $153,{ }^{67}$ inciso III da Constituição, tendo em vista exigência de imposto sobre situação que não configura renda; e, (iii) violação ao artigo $150,{ }^{68}$ inciso III, alíneas $a$ e $b$, da Constituição, pois o

\footnotetext{
${ }^{66}$ Art. 62: "Em caso de relevância e urgência, o Presidente da República poderá adotar medidas provisórias, com força de lei, devendo submetê-las de imediato ao Congresso Nacional, que, estando em recesso, será convocado extraordinariamente para se reunir no prazo de cinco dias. Parágrafo único. As medidas provisórias perderão eficácia, desde a edição, se não forem convertidas em lei no prazo de trinta dias, a partir de sua publicação, devendo o Congresso Nacional disciplinar as relações jurídicas delas decorrentes" (texto revogado pela EC $\mathrm{n}^{\circ}$ 32/2001).

${ }^{67}$ Art. 153: “Compete à União instituir impostos sobre:

(...)

III - renda e proventos de qualquer natureza"

${ }^{68} \mathrm{Art} .150$ "Sem prejuízo de outras garantias asseguradas ao contribuinte, é vedado à União, aos Estados, ao Distrito Federal e aos Municípios:

(...)

III - cobrar tributos:

a) em relação a fatos geradores ocorridos antes do início da vigência da lei que os houver instituído ou aumentado;
} 
parágrafo único do art. 74 da MP combatida pretende tributar lucros acumulados relativos a períodos anteriores à sua edição e também relativos ao mesmo exercício em que foi publicada. Vale dizer, que é objeto da presente discussão, apenas a tributação incidente sobre os lucros auferidos por coligadas e controladas no exterior, permanecendo inquestionada a matéria relativa às filiais e sucursais.

Um dos argumentos utilizados pelo Poder Executivo ${ }^{69}$ é que a equiparação entre lucros apurados e lucros disponibilizados se dá devido ao fato de que o poder de controle e o método de equivalência patrimonial já permitiam configurar a disponibilidade para os sócios dos lucros acumulados das sociedades estrangeiras por eles controladas ou a eles coligadas. $^{70}$ Especificamente, a Procuradoria-Geral da Fazenda Nacional aduz que:

\begin{abstract}
"realizado o balanço da pessoa jurídica controlada ou coligada no exterior - e verificada a existência de lucro - estes já estão na esfera de disponibilidade da controladora ou coligada no Brasil, que decidirá o destino de tais lucros. (...) Tanto lhe estão disponíveis que podem ser estes lucros. A) efetivamente pagos ou creditados a elas (disponibilidade econômica); ou podem elas deliberarem, p. ex, B) a sua destinação ao fundo de reserva da controlada ou coligada, implicando aumento na distribuição de ações ou majoração do valor das já existentes, hipótese esta em que o patrimônio da controladora ou coligada também sofrerá acréscimo (disponibilidade jurídica)".
\end{abstract}

A ADI foi levada a plenário, em fevereiro de 2003, pela Relatora Ministra Ellen Gracie, que proferiu o seu voto julgando parcialmente procedente o pedido da inicial, para considerar inconstitucional apenas o termo "ou coligadas" do art. 74 da MP 2.158-35/2001.

A Ministra afirma que no caso de empresas sediadas no Brasil, com relação aos lucros auferidos por controladas no exterior, "tem-se verdadeira

\footnotetext{
b) no mesmo exercício financeiro em que haja sido publicada a lei que os instituiu ou aumentou".

${ }^{69}$ Segundo constam das manifestações da Advocacia Geral da União (AGU) e da Procuradoria Geral da Fazenda Nacional (PGFN) nos autos da ADI 2.588.

${ }^{70}$ XAVIER, Alberto. Direito Tributário Internacional do Brasil. $6^{\mathrm{a}}$ ed. Rio de Janeiro: Editora Forense, 2004. p. 470.
} 
hipótese de aquisição da disponibilidade jurídica desses lucros no momento da sua apuração no balanço realizado pela controlada". Isso porque, segundo a Ministra, a sociedade controladora detém o poder decisório sobre o destino dos lucros ainda não remetidos ao Brasil, de forma que a disponibilidade dos lucros da controlada depende exclusivamente da controladora. Conclui que, "em conseqüência, a apuração de tais lucros caracteriza fato gerador do imposto de renda".

Ainda segundo a Ministra Ellen Gracie, a situação das sociedades coligadas é diferente, pois não há relação de controle ou influencia direta da sociedade brasileira na sociedade estrangeira. Ela aduz que: "não se pode falar em disponibilidade, pela coligada brasileira, dos lucros auferidos pela coligada estrangeira antes da efetiva remessa desses lucros", de modo que as coligadas não merecem o mesmo tratamento dado às filais e sucursais. Por fim, conclui quanto às coligadas que "segue, portanto, vigorando o disposto na Lei 9.532/97”.

Dando continuidade ao julgamento, em dezembro de 2004, o Min. Nelson Jobim votou pela improcedência da ADI. Em setembro de 2006, o Min. Marco Aurélio apresentou seu voto pela procedência da ação, seguido pelo Min. Sepúlveda Pertence, que acompanhou seu entendimento. Na mesma linha, pela procedência do pedido da ADI, votou o Min. Ricardo Lewandowski. Na seqüência, votou o Min. Eros Grau pela improcedência da ADI. Atualmente, a ADI se encontra com vista ao Min. Carlos Britto, com votação parcial de três votos pela procedência, dois pela improcedência e um pela procedência parcial do pedido.

Por tudo o quanto foi exposto, vale destacar o voto do Min. Marco Aurélio, ao discorrer sobre a impossibilidade de a lei tributária alterar 
conceitos e formas de direito privado $^{71}$ para desconsiderar a autonomia e independência entre controladora e controlada, e sociedades coligadas, no que diz respeito à propriedade dos lucros auferidos:

"Descabe o embaralhamento de institutos, expressões e vocábulos, como se cada qual não tivesse o sentido próprio indispensável a caminhar-se com segurança jurídica. A empresa possuidora de personalidade jurídica não se confunde com outra, pouco importando se tenha a coligação ou o controle, espécies societárias que não levam à simbiose a ponto de, em promiscuidade ímpar, confundir as peculiaridades no que são próprias".

Corroborando este entendimento, o Min. Sepúlveda Pertence complementa sobre a ficção jurídica:

"Não posso ver, na referência a um imposto sobre a renda, a possibilidade de fazê-lo incidir sobre o que renda não é, ainda que seja a partir de uma ficção de desconsideração da personalidade jurídica, conforme assinalou bem o voto do Ministro Marco Aurélio, que pressupõe fraude e, assim, há de ser apurado em concreto".

Portanto, apesar de três votos favoráveis à declaração da inconstitucionalidade do artigo 74 e do parágrafo único, da Medida Provisória $\mathrm{n}^{\mathrm{o}}$ 2.158-35/2001, a matéria ainda está longe de um pronunciamento final pelo Supremo Tribunal Federal.

${ }^{71}$ Art. 110, do CTN: "A lei tributária não pode alterar a definição, o conteúdo e o alcance de institutos, conceitos e formas de direito privado, utilizados, expressa ou implicitamente, pela Constituição Federal, pelas Constituições dos Estados, ou pelas Leis Orgânicas do Distrito Federal ou dos Municípios, para definir ou limitar competências tributárias". 


\section{Capítulo VII - Conclusão}

Conforme demonstrado, a implementação da universalidade na tributação da renda das pessoas jurídicas no Brasil tratou indiscriminadamente a forma como o imposto de renda incide sobre os lucros auferidos no exterior. Como já discutido, atualmente, as sociedades sediadas no Brasil estão sujeitas à tributação dos lucros que auferirem no exterior, seja por meio de filiais, sucursais, coligadas ou controladas, na data em que tais lucros forem apurados em balanço.

A problemática da tributação pelo IR quando da apuração dos lucros em balanço levantado pela sociedade estrangeira, filial ou sucursal, cinge a presunção de que tais lucros foram ou serão efetivamente disponibilizados para a sociedade sediada no Brasil.

Como bem determina a Lei $\mathrm{n}^{\circ}$ 9.532/97, o tratamento dado às controladas, coligadas, filiais e sucursais deve ser diferenciado. Isso porque, não se tratam de quatro formas societárias semelhantes de se explorar determinada atividade econômica no exterior. As filiais e sucursais são extensões operacionais de uma mesma pessoa jurídica, ou seja, sua atuação se faz na representação daquela tida como matriz, sediada no Brasil. Notese que para fins mercantis há sutil distinção entre sucursal e filial, mas isso não implica em importância relevante para o direito tributário. Nesse sentido, a tributação de lucros auferidos no exterior pelas filiais e sucursais não apresenta maiores mistérios. $\mathrm{O}$ art. $1^{\circ}, \S 1^{\circ}$, alínea $a$, da Lei $\mathrm{n}^{\circ}$ 9.532/97, atualmente em vigor, determina que os lucros por elas auferidos são considerados disponibilizados na data do levantamento do balanço em que os tiver apurado. Diferente não poderia ser, pois o levantamento do balanço da filial ou sucursal é nada menos do que o levantamento do balanço de uma parte operacional específica que compõe uma mesma pessoa jurídica sediada no Brasil. Verificada a existência de lucros, não há de se falar em 
distribuição dos mesmos, pois eles já são de propriedade da empresa brasileira, ou seja, já se encontram disponíveis, ensejando a ocorrência do fato gerador do imposto de renda.

Tratamento diverso deve ser considerado no tocante às coligadas e controladas. Os dois tipos de sociedades não guardam qualquer relação de dependência com a sociedade investidora brasileira, pois sua única ligação está no fato de que a sociedade brasileira é detentora de um investimento parte do capital social aportado - na sociedade estrangeira. A MP n ${ }^{\circ} 2.158$ $35 / 2001$ pretendeu aplicar às coligadas e controladas o mesmo tratamento dado às filiais e sucursais pela Lei $\mathrm{n}^{\circ}$ 9.532/97, o que restabeleceu a regra primitiva da Lei $n^{\circ}$ 9.249/95, em que não havia distinção entre filiais, sucursais, coligadas e controladas para fins de disponibilidade dos lucros por elas auferidos no exterior.

A mencionada pretensão envolve questões um tanto mais delicadas. Partindo-se do princípio que não há qualquer relação de dependência entre a sociedade brasileira e a estrangeira, temos que a análise da regra-matriz do imposto de renda pressupõe, além da verificação da existência de lucros através do levantamento do balanço, o acréscimo patrimonial experimentado pela sociedade no Brasil através da aquisição da disponibilidade desses lucros previamente distribuídos em assembléia.

Como vimos, em direito societário, só ocorre a distribuição de lucros após sua deliberação em assembléia, razão pela qual, antes da referida assembléia não há de se falar em disponibilização de lucros aos sócios. No entanto, em contrapartida, se os sócios, em assembléia, têm o poder de deliberar sobre distribuir ou não os lucros verificados, pode-se dizer que eles os têm disponibilizados. Nesse ponto, é bastante convincente a tese da PGFN apresentada nos autos da ADI $n^{\circ}$ 2.588. Porém, por mais que deliberar sobre o destino dos lucros seja considerado poder de dispor dos 
mesmos, caso o sócio opte por reinvesti-los na sociedade estrangeira, ele não estaria a experimentar acréscimo patrimonial tributável pelo imposto de renda. O que ocorreria, seria apenas a valorização do seu investimento pelo método da equivalência patrimonial, que possui determinação expressa na legislação quanto a não constituir fato gerador do IRPJ.

Para melhor elucidarmos a questão, é interessante tomar um caso prático como exemplo. Imaginemos a constituição de uma sociedade no Brasil, com capital social de dois milhões de reais. Metade do dinheiro em caixa - que é igual ao capital social - é utilizado para adquirir $60 \%$ das ações de determinada sociedade em outro país, e a outra metade utilizada na aquisição de matéria-prima e custeio de suas operações no Brasil. A situação hipotética demonstra, claramente, que a sociedade brasileira encontra-se na condição de controladora da sociedade estrangeira, situandose, portanto, sob a determinação do art. 74 da MP 2.158-35/2001.

Suponhamos que ao final do primeiro ano de operações, a sociedade brasileira obteve um milhão e quinhentos mil reais de receita, e gastou um milhão de reais nas suas operações. Por conseguinte, certo que tudo o que a sociedade brasileira possui em caixa são quinhentos mil reais, visto que o outro milhão inicial foi utilizado na compra das ações da sociedade estrangeira, a base de cálculo, ou seja, o seu lucro real tributável pelo IRPJ seria de quinhentos mil reais.

Com a determinação do art. 74 da MP, faz-se necessário apurar os lucros da controlada. Nesse caso, se a controlada apurar lucros totalizando o equivalente a cem milhões de reais, $60 \%$ disso deverão ser somados aos quinhentos mil reais, para que se proceda à apuração do lucro real da controladora. Temos, então, que a base de cálculo do IRPJ da controlada é de sessenta milhões e quinhentos mil reais, o que nos leva à conclusão de que o imposto a pagar superará em muito, a quantia por ela efetivamente 
disponível - quinhentos mil reais -, para o pagamento do imposto de renda. Isso tudo porque, como controladora, a sociedade optou por não distribuir nada dos lucros apurados, tendo em vista que reinvestir na ampliação de fábricas fazia parte da sua estratégia de expansão.

A situação hipotética acima mostra, claramente, o efeito de confisco decorrente da tributação de lucros efetivamente não disponibilizados. Por fim, as coligadas estariam sujeitas ao mesmo efeito, pois a única diferença seria a ausência de poder de controle.

Poderíamos nos filiar à idéia de que a realização da equivalência patrimonial, por si só, mostra que há disponibilidade da renda por parte da controladora. Contudo, a variação positiva do MEP é isenta de tributação pelo IRPJ, dentre outros motivos, pelo fato de nela estar incluída a variação cambial. O efeito da tributação seria desastroso, em um cenário de supervalorização da moeda estrangeira, pois a controladora no Brasil teria de recolher imposto de renda sobre a variação positiva de um ativo que não representou ganho financeiro efetivo, mas tão somente valorização cambial.

Por fim, da maneira como está, a legislação brasileira não satisfaz as necessidades de se tributar a renda pelo princípio da universalidade levando-se em consideração os casos de planejamento fiscal envolvendo paraísos fiscais - principal razão do surgimento da idéia de se tributar a renda mundial. A implantação de regimes de transparência fiscal exige refinamento e técnica na criação de hipóteses legais que devem sempre observar a independência e a personalidade jurídica autônoma das sociedades, o que não está sendo levado em conta pela legislação atualmente vigente, no tocante às sociedades coligadas e controladas. 


\section{BiblografiA}

ALVES, Taciana Stanislau Afonso Bradley Alves. O Princípio da Renda Mundial no Direito Brasileiro. In: TÔRRES, Heleno Taveira (Coord.). Direito Tributário Internacional Aplicado. São Paulo: Quartier Latin, 2003. p. 605-639.

ÁVILA, Humberto. O Imposto de Renda, a Contribuição Social sobre o Lucro e os Lucros Auferidos no Exterior. In: ROCHA, Valdir de Oliveira (Coord.). Grandes questões atuais do Direito Tributário. v. 7. São Paulo: Dialética, 2003. p. 215-240.

BALEEIRO, Aliomar; DERZI, Misabel Abreu Machado. Direito Tributário Brasileiro. 11ª ed.. São Paulo: Editora Forense, 2003. 1063p.

BOITEUX, Fernando Netto. As Sociedades Coligadas, Controladoras, Controladas, e a Tributação dos Lucros Obtidos no Exterior. Revista Dialética de Direito Tributário. São Paulo, n. 105, jun. 2004. p. 20-33.

BORBA, José Edwaldo Tavares. Direito Societário. $7^{\mathrm{a}}$ ed. Rio de Janeiro: Renovar, 2001. 610p.

CANTO, Gilberto de Ulhôa. Presunções no Direito Tributário. In: MARTINS, Ives Gandra da Silva (Coord.). Cadernos de pesquisas tributárias: Presunções no Direito Tributário. v. 9. São Paulo: Resenha Tributária, 1991. p. 1-33. . Estudos e Pareceres de Direito Tributário.

São Paulo: Revista dos Tribunais, 1975. 518p. 
CARRAZZA, Roque Antonio. Imposto sobre a Renda: perfil constitucional e temas específicos. São Paulo: Malheiros, 2005. 551p.

. Curso de Direito Constitucional Tributário.

9a ed.. São Paulo: Malheiros, 1997. 500p.

CARVALHO, Paulo de Barros. Fundamentos Jurídicos da Incidência Tributária. São Paulo: USP, 1996. 163p.

COÊLHO, Sasha Calmon Navarro; DERZI, Misabel Abreu Machado. Tributação pelo IRPJ e pela CSLL de Lucros auferidos por empresas controladas ou coligadas no exterior - Inconstitucionalidade do art. 74 da Medida Provisória no 2.158-35/01. Revista Dialética de Direito Tributário. São Paulo, n. 130, jul. 2006. p. 135-149.

DERZI, Misabel Abreu Machado. A Tributação dos Lucros Auferidos no Exterior por Subsidiárias, Controladas e Coligadas e os Paraísos Fiscais. In: ROCHA, Valdir de Oliveira (Coord.). Grandes questões atuais do Direito Tributário. v. 9. São Paulo: Dialética, 2005. p. 411-429. - Correção Monetária e Demonstrações

Financeiras - Conceito de Renda - Imposto sobre patrimônio - lucros fictícios - direito adquirido a deduções e correções - Lei 8.200/91. Revista de Direito Tributário. São Paulo, n. 59. p. 124-159.

FERREIRA, Waldemar. Tratado de Direito Comercial: O Estatuto do Estabelecimento e a Emprêsa Mercantil. v. 6. São Paulo: Saraiva, 1962. $708 p$.

GONÇALVES, José Artur Lima. Imposto sobre a renda: Pressupostos constitucionais. São Paulo: Malheiros, 1997. 228p. 
HIGUCHI, Hiromi; HIGUCHI, Fábio Hiroshi; HIGUCHI, Celso Hiroyuki. Imposto de Renda das Empresas: Interpretação e prática. $33^{a}$ ed.. São Paulo: IR Publicações Ltda., 2008. 928p.

IUDÍCIBUS, Sérgio de; MARTINS, Eliseu; GELBCKE, Ernesto Rubens. Manual de Contabilidade das Sociedades por Ações: Aplicável às demais sociedades. $7^{\mathrm{a}}$ ed. São Paulo: Editora Atlas, 2007. 646p.

MACHADO, Hugo de Brito. Comentários ao Código Tributário Nacional: Artigos $1^{\circ}$ a 95. v. 1. São Paulo: Editora Atlas, 2003. 735p.

Curso de Direito Tributário. $29^{\mathrm{a}}$ ed.. São

Paulo: Malheiros, 2008. 543p.

MATTOS, Aroldo Gomes de. Lucros, prejuízos e perdas, apurados no exterior. Tratamento tributário no Brasil. In: ROCHA, Valdir de Oliveira (Coord.). Grandes questões atuais do direito tributário. v. 6. São Paulo: Dialética, 2002. p. 9-29.

MOSQUERA, Roberto Quiroga. Renda e proventos de qualquer natureza: o imposto e o conceito constitucional. São Paulo: Dialérica, 1996. 142p.

OKUMA, Alessandra. Da Tributação das Empresas Coligadas e Controladas. In: TÔRRES, Heleno Taveira (Coord.). Direito Tributário Internacional aplicado. v. 2. São Paulo: Quartier Latin, 2004. p. 503-534.

OLIVEIRA, Ricardo Mariz de. O Conceito de Renda - Inovação do art. 43 do CTN pela Lei Complementar n ${ }^{\circ} 104$ (a Questão da Disponibilidade sobre Lucros de Coligadas e Controladas no Exterior). Revista Dialética de Direito Tributário. São Paulo, n. 73, out. 2001.p. 105-115. 
PAULSEN, Leandro. Direito Tributário: Constituição e Código Tributário à luz da doutrina e da jurisprudência. $10^{\mathrm{a}}$ ed.. Porto Alegre: Livraria do Advogado, 2008. 1420p.

PEDREIRA, José Luiz Bulhões. Imposto sobre a Renda: Pessoas Jurídicas. v. 1. Rio de Janeiro: Adcoas/Justec, 1979. 568p.

QUEIROZ, Luís César Souza de. Imposto sobre a Renda: Requisitos para uma tributação constitucional. Rio de Janeiro: Editora Forense, 2003. 371p.

ROTHMANN, Gerd Willi. Tributação Internacional sem sujeito passivo: uma nova modalidade do imposto de renda sobre ganhos de capital. In: ROCHA, Valdir de Oliveira (Coord.). Grandes questões atuais do Direito Tributário. v. 10. São Paulo: Dialética, 2006. p. 106-161.

SCHOUERI, Luís Eduardo; NETO, Miguel Hilu. Sobre a Tributação dos "Lucros Disponibilizados" do Exterior. In: ROCHA, Valdir de Oliveira (Coord.). Imposto de Renda: alterações fundamentais. v. 2. São Paulo: Dialética, 1998. p. 113-141.

TÔRRES, Heleno Taveira. Pluritributação internacional sobre as rendas de empresas. $2^{\mathrm{a}}$ ed.. São Paulo: Revista dos Tribunais, 2001. 846p.

Princípio da Territorialidade e Tributação de Não-Residentes no Brasil. Prestações de Serviços no Exterior. Fonte de Produção e Fonte do Pagamento. In: TÔRRES, Heleno Taveira (Coord.). Direito Tributário Internacional aplicado. São Paulo: Quartier Latin, 2003. p. 71-108. 
Direito Tributário Internacional: Planejamento tributário e operações transnacionais. São Paulo: Revista dos Tribunais, 2001. 667p.

Direito Tributário e Direito Privado: autonomia privada, simulação, elusão tributária. São Paulo: Revista dos Tribunais, 2003. 510p.

TORRES, Ricardo Lobo. Tratado de Direito Constitucional Financeiro e Tributário: Os Tributos na Constituição. v. 4. Rio de Janeiro: Renovar, 2007. 755p.

TENÓRIO, Oscar. Direito internacional privado. $10^{\mathrm{a}}$ ed. São Paulo: Freitas Bastos, 1970. 455p.

WALD, Arnoldo. In: TEIXEIRA, Sálvio de Figueired (Coord.). Comentários ao Novo Código Civil: Livro II - Do Direito de Empresa, arts. 966 a 1.195. v. 14. Rio de Janeiro: Editora Forense, 2005. 995p.

XAVIER, Alberto. Direito Tributário Internacional do Brasil. $6^{\mathrm{a}}$ ed. Rio de Janeiro: Editora Forense, 2004. 904p.

Direito Tributário Internacional do Brasil. $5^{\mathrm{a}}$ ed. Rio de Janeiro: Editora Forense, 2002. p. 731p.

TRF $4^{\mathrm{a}}$ Região, Apelação em Mandado de Segurança $\mathrm{n}^{\mathrm{o}}$ 2002.70.00.069334-0, Rel. Des. Federal Dirceu de Almeida Soares, Porto Alegre, 06 dez. 2005. DJU 15 fev. 2006. 
STJ, RESP n ${ }^{\circ}$ 907.404/PR, Rel. Min. Humberto Martins, Brasília, 23 out. 2007. DJU 13 nov. 2007.

STF, ADI n 2.588, Rel. Min. Ellen Gracie, Brasília, em julgamento. 